【カテゴリー II

日本建築学会構造系論文集 第81巻 第720号, 179-189，2016年2月

J. Struct. Constr. Eng., AIJ, Vol. 81 No. 720, 179-189, Feb., 2016 DOI http://doi.org/10.3130/aijs.81.179

\title{
フライアッシュを混合したコンクリートの中性化進行に関する定量的検討 QUANTITATIVE STUDY ON CARBONATION PROGRESS OF CONCRETE USING FLY ASH
}

\author{
財津拓三*, 杉山 央**, 小林利充***, 陣 内 浩**** \\ Takumi ZAITSU, Hisashi SUGIYAMA, Toshimitsu KOBAYASHI \\ and Hiroshi JINNAI
}

\begin{abstract}
We simultaneously studied increase in carbonation inhibition effect by densification of the concrete structure due to pozzolanic reaction and decrease in the same due to consumption of $\mathrm{Ca}(\mathrm{OH})_{2}$, and we attempted to shed light on the effect of mixing fly ash on the durability of concrete with the help of accelerated carbonation test. As a result, In the concrete having the same water-cement ratio, we studied carbonation inhibition effect by combining the effect of consumption of $\mathrm{Ca}(\mathrm{OH})_{2}$ due to pozzolanic reaction of fly ash and increase in compressive strength. Based on the compressive strength of concrete and $\mathrm{Ca}(\mathrm{OH})_{2}$ amount, we could demonstrate the carbonation inhibition effect of fly ash mixed concrete.
\end{abstract}

Keywords : Fly ash, Pozzolanic reaction, Compressive strength, Carbonation-resistant property, Curing condition, X-ray diffraction analysis フライアッシュ, ポゾラン反応, 圧縮強度, 中性化抵抗性, 養生条件, X線回折分析

\section{1. はじめに}

石炭を燃料とする火力発電所から排出されるフライアッシュ（以 降、FA と表記）は、混合セメントの原料として、またコンクリー 卜の混和材料として利用されている。昨今の社会情勢から、火力発 電所への依存が高まっており、なお一層の FA の積極的利用が望ま れている。 FA はセメントの水和反応により生成した $\mathrm{Ca}(\mathrm{OH})_{2}$ と反 応 (ポゾラン反応) するため、FA を混合するとコンクリート中の $\mathrm{Ca}(\mathrm{OH})_{2}$ が消費され、FA 無混合のコンクリートと異なる中性化進 行を示すことが明らかにされている1)。このため、FAを混合したコ ンクリートを建築物に使用する場合は種々の制限が設けられている。 例えば、「住宅の品質の確保の促進等に関する法律」では耐久性を確 保するために水セメント比の上限が定められており、等級にもよる が、フライアッシュセメントを使用する場合は FA を除いて水セメ ント比を算定することになっている。日本建築学会建築工事標準仕 様書・同解説 JASS 5 鉄筋コンクリート工事 2)では、計画供用期間 が超長期の場合はフライアッシュセメントの使用が認められておら ず、また同会フライアッシュを使用するコンクリートの調合設計・ 施工指針・同解説 3)では、FA を混合寸る場合は耐久設計基準強度の 割増しを行うことが定められている。
その一方で、FA はポゾラン反応によってコンクリート組織を緻 密化させるため、強度増加に寄与寸る ${ }^{4), 5}$ ) とともに、外部からの $\mathrm{CO}_{2}$ の侵入を抑制する。このため、FA の混合が必ずしも中性化抵抗性 に対してマイナスの影響ばかりを与えるとはいえず、FA の混合が 中性化抵抗性に及ぼす影響については組織の緻密化と $\mathrm{Ca}(\mathrm{OH})_{2}$ の 減少の両面から論じる必要があると指摘されている ${ }^{6,7)}$ 。また、FA 混合による影響はコンクリートの調合や養生条件などによって異な ることも考えられ、FA の一層の有効利用のために、その影響を定 量的に把握しておく必要がある。

そこで、本研究では FA 混合によるコンクリート組織の緻密化に 起因した中性化抵抗性の向上と、 $\mathrm{Ca}(\mathrm{OH})_{2}$ の消費に起因した中性化 抵抗性の低下の影響を定量的に解明することを目的として、3 シリ ーズの実験を行った。シリーズ I では、FA を各種調合のコンクリ ートに混合し、各種養生した場合の圧縮強度への影響を調査した。 シリーズ II では、促進中性化試験を行い、FA の混合による中性化 抵抗性への影響を調查した。シリーズIII では、促進中性化試験後の コンクリートを用いて X 線回折分析（以降、XRD 分析と表記）を 行い、FA のポゾラン反応による $\mathrm{Ca}(\mathrm{OH})_{2}$ の消費状況を調査した。
* 宇都宮大学大学院工学研究科 大学院生 · 修士 (工学)

** 宇都宮大学大学院工学研究科 教授・博士 (工学)

*** (株)大林組技術研究所 主任研究員 - 博士 (工学)

**** 大成建設侏技術センター 主席研究員・博士 (工学)
Grad. Stud., Dept. of Architecture, Utsunomiya Univ., M.Eng.

Prof., Dept. of Architecture, Utsunomiya Univ., Dr.Eng.

Chief Research Engineer, Technical Research Institute, Obayashi Corp., Dr.Eng.

Chief Research Engineer, Technology Center, Taisei Corp., Ph.D. 


\section{2. 実験計画}

\section{1 コンクリートの使用材料}

表 1 に、コンクリートの使用材料および物性を示す。細骨材には、 砕砂 $\mathrm{S} 1$ と川砂 $\mathrm{S} 2$ を質量比で $\mathrm{S} 1: \mathrm{S} 2=55: 45$ の割合で混合した混 合砂（混合後の F.M.は 2.74）を用いた。粗骨材は砕石 5 号（粒径 13〜20mm）と砕石 6 号（粒径 5〜13mm）を等量混合して用いた。 表 1 には、混合後の粗骨材の物性值を示した。

表 2 に、本実験で使用した FA の品質を示す。既往の研究 8),9)で報 告されているように、燃料となる石炭の産出国や燃焼ボイラー等の 設備の違いにより排出される FA の品質は異なる。このため、生産 地の異なる FA を使用したコンクリートでは、強度や中性化などへ の影響が異なることが予想されるが、本研究では、同一発電所で生 産された JIS A 6201 に規定されるII 種に該当する 1 種類の FA のみ を使用し、調合や養生条件などの水準を数多く計画することとした。

\section{2 コンクリートの調合}

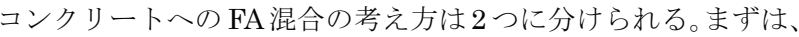
普通ポルトランドセメント（以降、セメントと表記）の量は変えず に FA を混和材として混合する方法（外割り混合）である。本稿で は、このコンクリートを FA 外割り混合コンクリートと表記する。 また、コンクリート $1 \mathrm{~m}^{3}$ 中の FA の質量をセメントの質量で除した 值を FA 外割り混合率と表記する。

もう一方は、JIS R 5213 に規定されているフライアッシュセメン トのように、セメントの一部として FA を混合する方法（内割り混 合）である。本稿では、このコンクリートを FA 内割り混合コンク リートと表記する。また、コンクリート $1 \mathrm{~m}^{3}$ 中の FA の質量をセメ ントの質量と FA の質量の和で除した值を FA 内割り混合率と表記 する。表 3 に示寸 FA 外割り混合率について、本研究では FA をセ メントに対して外割り混合または内割り混合した場合の両面から圧 縮強度および中性化の進行を検討するため、水セメント比（W/C) と水結合材比（W/B）の組み合せを設定し、それに応じて FA 外割 り混合率を定める手順で調合を計画した。なお、結合材（B）とは セメントと FA を合わせたもの $(\mathrm{C}+\mathrm{FA})$ である。

表 4 に、コンクリートの調合を示す。各コンクリートに共通して、 単位水量を $175 \mathrm{~kg} / \mathrm{m}^{3}$ 、粗骨材かさ容積を $0.59 \mathrm{~m}^{3} / \mathrm{m}^{3}$ とした。また、 フレッシュコンクリートの目標空気量を $4.5 \%$ とした。PLを付した 調合記号は FA を混合しないコンクリートを表し、以降、PL コンク リートと表記する。また、FA**（*** FA 外割り混合率(\%)を 示す）を付した調合記号は FA を混合したコンクリートを表し、FA 外割り混合コンクリートとして記号を定めた。表 4 には、コンクリ ートのフレッシュ試験結果も示す。

\section{3 実験方法}

\subsection{1 シリーズ I（圧縮強度）}

コンクリートの練混ぜには容量 55 リットルのパン型ミキサを用 いまずセメント、FAおよび細骨材を投入して 15 秒間練り混ぜた。 その後、あらかじめ化学混和剤を混合した練混ぜ水を投入して 60 秒間練り混ぜ、さらに粗骨材を投入して 60 秒間練り混ぜた。

練混ぜ後のコンクリートを軽量型枠（ $\phi 100 \times 200 \mathrm{~mm} ）$ に打ち込 み、上面をポリ塩化ビニリデン製ラップで包んで封かん状態とした。 この状態で温度 $20^{\circ} \mathrm{C}$ もと行う養生を湿潤養生とし、7 日間を標準 とした。湿潤養生終了後（脱型後）は、温度 $20^{\circ} \mathrm{C}$ 、湿度 $60 \% \mathrm{RH}$ の
表 1 コンクリートの使用材料および物性

\begin{tabular}{|c|c|c|c|}
\hline 材 & 料 & 記号 & 種類および物性 \\
\hline \multicolumn{2}{|c|}{ セメント } & $\mathrm{C}$ & $\begin{array}{l}\text { 普通ポルトランドセメント密度: } 3.16 \mathrm{~g} / \mathrm{cm}^{3} \\
\text { 比表面積: } 3310 \mathrm{~cm}^{2} / \mathrm{g} 、 \mathrm{C}_{3} \mathrm{~S}: 56 \% 、 \mathrm{C}_{2} \mathrm{~S}: 19 \% \text { 、 } \\
\mathrm{C}_{3} \mathrm{~A}: 9 \% 、 \mathrm{C}_{4} \mathrm{AF}: 9 \%\end{array}$ \\
\hline \multicolumn{2}{|c|}{ フライアッシュ } & FA & JIS A $6201 \quad$ II 種 舞鶴発電所産 \\
\hline \multicolumn{2}{|c|}{ 練混ぜ水 } & $\mathrm{W}$ & 栃木県小山市水道水 \\
\hline \multirow{2}{*}{ 細骨材 } & \multirow{2}{*}{$\begin{array}{l}\text { 混 } \\
\text { 合 } \\
\text { 砂 }\end{array}$} & $\mathrm{S} 1$ & $\begin{array}{l}\text { 硬質砂岩砕砂(栃木県鹿沼産) } \\
\text { 表乾密度:2.61g/cm }{ }^{3} \text { 吸水率:1.18\%、F.M.:2.99 }\end{array}$ \\
\hline & & $\mathrm{S} 2$ & $\begin{array}{l}\text { 川砂(栃木県鬼怒川産) } \\
\text { 表乾密度:2.59g/ } / \mathrm{cm}^{3} \text { 、吸水率:2.51\%、F.M.:2.41 }\end{array}$ \\
\hline \multicolumn{2}{|c|}{ 粗骨材 } & $\mathrm{G}$ & 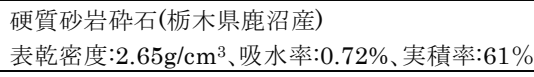 \\
\hline \multirow{4}{*}{\multicolumn{2}{|c|}{ 化学混和剂 }} & Ad1 & 高性能 AE 減水剤:ポリカルボン酸エーテル系 \\
\hline & & Ad2 & $\begin{array}{l}\text { 高機能タイプ AE 減水剂: リグニンスルホン酸 } \\
\text { 化合物とポリカルボン酸エーテルの複合型 }\end{array}$ \\
\hline & & Ad3 & $\begin{array}{l}\mathrm{AE} \text { 剤 1: 高アルキルカルボン酸系陰イオン界面 } \\
\text { 活性剤と非イオン界面活性剤との複合型 }\end{array}$ \\
\hline & & $\operatorname{Ad} 4$ & $\begin{array}{l}\mathrm{AE} \text { 剤 } 2 \text { (低水セメント比用): 高アルキルカルボ } \\
\text { ン酸系陰イオン界面活性剤と非イオン界面活性 } \\
\text { 剤との複合型 }\end{array}$ \\
\hline
\end{tabular}

表 2 フライアッシュの品質

\begin{tabular}{|c|c|c|c|}
\hline \multicolumn{3}{|c|}{ 目 } & 試験值 \\
\hline \multirow{9}{*}{ 物 } & \multicolumn{2}{|c|}{ 密度 $\left(\mathrm{g} / \mathrm{cm}^{3}\right)$} & 2.25 \\
\hline & \multicolumn{2}{|c|}{ 比表面積 $\left(\mathrm{cm}^{2} / \mathrm{g}\right)$} & 3616 \\
\hline & \multicolumn{2}{|c|}{ 45um ふるい残分 (\%) } & 4.2 \\
\hline & \multicolumn{2}{|c|}{ フロー值比 $(\%)$} & 109 \\
\hline & \multirow{2}{*}{ 活性度指数（\%) } & 28 日 & 86 \\
\hline & & 91 日 & 98 \\
\hline & \multicolumn{2}{|c|}{ 強熱減量 $(\%)$} & 2.1 \\
\hline & \multicolumn{2}{|c|}{ 湿分 (\%) } & 0.1 \\
\hline & \multicolumn{2}{|c|}{$\mathrm{pH}$} & 9.7 \\
\hline \multirow{5}{*}{$\begin{array}{c}\text { 化学成分 } \\
(\%)\end{array}$} & \multicolumn{2}{|c|}{$\mathrm{SiO}_{2}$} & 61.8 \\
\hline & \multicolumn{2}{|c|}{$\mathrm{Al}_{2} \mathrm{O}_{3}$} & 25.9 \\
\hline & \multicolumn{2}{|c|}{$\mathrm{Fe}_{2} \mathrm{O}_{3}$} & 4.3 \\
\hline & \multicolumn{2}{|c|}{$\mathrm{CaO}$} & 1.7 \\
\hline & \multicolumn{2}{|c|}{$\mathrm{MgO}$} & 0.5 \\
\hline
\end{tabular}

表 3 水セメント比と水結合材比の関係

\begin{tabular}{|c|c|c|c|c|c|c|}
\hline \multirow{2}{*}{\multicolumn{2}{|c|}{$\begin{array}{c}\mathrm{FA} \text { 外割り混合率 }(\%) \\
\mathrm{FA} / \mathrm{C} \times 100\end{array}$}} & \multicolumn{5}{|c|}{ 水セメント比（\%） } \\
\hline & & 30 & 40 & 50 & 60 & 70 \\
\hline \multirow{5}{*}{$\begin{array}{c}\text { 水結合材比 } \\
(\%)\end{array}$} & 30 & 0 & 33 & 67 & - & - \\
\hline & 40 & - & 0 & 25 & 50 & - \\
\hline & 50 & - & - & 0 & 20 & 40 \\
\hline & 60 & - & - & - & 0 & 17 \\
\hline & 70 & - & - & - & - & 0 \\
\hline
\end{tabular}

環境において気中養生を行った。これは、所定期間の湿潤養生後は 気中養生としたため、以降、気中養生と表記する。また、水セメン ト比 $50 \%$ の調合のコンクリートについては、湿潤養生 3 日間および 10 日間、ならびに圧縮強度試験材齢までの継続的な湿潤養生も計画 した。なお、すべての調合において、標準養生 $\left(20^{\circ} \mathrm{C}\right.$ 水中 $)$ 供試体 も作製した。圧縮強度試験は材齢 28 日および 91 日において JIS A 1108 に従って行った。表 5 は、シリーズ I 、後述のシリーズIおよ びIIIにおいて計画した湿潤養生期間を示す。

\subsection{2 シリーズII（促進中性化）}

練混ぜ後のコンクリートをウレタン塗装合板で作製した型枠に打 ち込み、角型供試体 $(100 \times 100 \times 400 \mathrm{~mm})$ を作製した。材齢 28 日 
表 4 シリーズ I および IIにおけるコンクリートの調合とフレッシュ性状

\begin{tabular}{|c|c|c|c|c|c|c|c|c|c|c|c|c|c|c|c|c|c|}
\hline \multirow[b]{2}{*}{$\begin{array}{l}\text { 調合 } \\
\text { 記号 }\end{array}$} & \multirow[b]{2}{*}{$\begin{array}{l}\mathrm{W} / \mathrm{C} \\
(\%)\end{array}$} & \multirow[b]{2}{*}{$\begin{array}{l}\text { W/B } \\
(\%)\end{array}$} & \multirow{2}{*}{$\begin{array}{c}\text { FA 外割り } \\
\text { 混合率 } \\
(\%) \\
\end{array}$} & \multirow{2}{*}{$\begin{array}{c}\text { FA 内割り } \\
\text { 混合率 } \\
(\%) \\
\end{array}$} & \multirow[b]{2}{*}{$\begin{array}{l}\text { s/a } \\
(\%)\end{array}$} & \multicolumn{6}{|c|}{ 単位量 $\left(\mathrm{kg} / \mathrm{m}^{3}\right)$} & \multicolumn{4}{|c|}{ 化学混和剂添加量 $\left(\mathrm{kg} / \mathrm{m}^{3}\right)$} & \multicolumn{2}{|c|}{ フレッシュ試験結果 } \\
\hline & & & & & & $\mathrm{W}$ & $\mathrm{C}$ & FA & S1 & S2 & G & Ad1 & $\operatorname{Ad} 2$ & $\operatorname{Ad} 3$ & $\operatorname{Ad} 4$ & $\begin{array}{c}\text { スランプ値 } \\
(\mathrm{cm})\end{array}$ & $\begin{array}{c}\text { 空気量 } \\
(\%)\end{array}$ \\
\hline 30PL & 30 & 30 & - & - & 40 & 175 & 583 & - & 340 & 278 & 948 & 4.1 & - & - & 2.3 & 23.5 & 5.0 \\
\hline 40PL & \multirow{2}{*}{40} & 40 & - & - & 44 & \multirow{2}{*}{175} & \multirow{2}{*}{438} & - & 406 & 332 & \multirow{2}{*}{948} & - & 3.5 & 2.6 & - & 22.5 & 5.9 \\
\hline 40FA33 & & 30 & 33 & 25 & 38 & & & 146 & 313 & 256 & & 3.5 & - & - & 23.3 & 20.5 & 5.3 \\
\hline $50 \mathrm{PL}$ & \multirow{3}{*}{50} & 50 & - & - & 47 & \multirow{3}{*}{175} & \multirow{3}{*}{350} & - & 446 & 365 & \multirow{3}{*}{948} & - & 2.5 & 2.1 & - & 19.5 & 4.2 \\
\hline 50FA25 & & 40 & 25 & 20 & 43 & & & 88 & 390 & 319 & & - & 2.2 & 13.1 & - & 19.0 & $\begin{array}{l}3.5 \\
3.5\end{array}$ \\
\hline 50FA67 & & 30 & 67 & 40 & 37 & & & 233 & 297 & 243 & & 3.5 & - & - & 23.3 & 20.5 & 5.1 \\
\hline 60PL & \multirow{3}{*}{60} & 60 & $\ldots$ & - & 48 & \multirow{3}{*}{175} & \multirow{3}{*}{292} & $\ldots$ & 472 & 386 & \multirow{3}{*}{948} & $\ldots$ & 5.3 & 3.5 & $\ldots$ & 21.0 & 4.6 \\
\hline 60FA20 & & 50 & 20 & 17 & 46 & & & 58 & 435 & 356 & & - & 1.6 & 12.3 & - & 22.5 & 5.0 \\
\hline 60FA50 & & 40 & 50 & 33 & 43 & & & 146 & 379 & 310 & & - & 2.6 & 19.7 & - & 20.0 & 4.0 \\
\hline 70PL & \multirow{3}{*}{70} & 70 & - & - & 49 & \multirow{3}{*}{175} & \multirow{3}{*}{250} & - & 491 & 402 & \multirow{3}{*}{948} & - & 2.5 & 1.0 & - & 18.5 & 3.8 \\
\hline 70FA17 & & 60 & 17 & 14 & 48 & & & 42 & 465 & 380 & & - & 1.5 & 11.7 & - & 22.0 & 5.8 \\
\hline 70FA40 & & 50 & 40 & 29 & 46 & & & 100 & 427 & 350 & & - & 1.1 & 21.0 & - & 21.0 & 3.5 \\
\hline
\end{tabular}

※表中の Ad3 およびAd4 については、原液を 100 倍に希䣋した液体の添加量を示している。

までシリーズ I と同様の養生を行った後は、材齢 56 日まで気中養 生を行った。標準養生供試体については、材齢 28 日まで水中養生 し、その後は 56 日まで温度 $20^{\circ} \mathrm{C}$ 、湿度 $60 \% \mathrm{RH}$ の室内に静置した。 材齢 56 日に供試体の中性化深さ測定面以外をアルミテープでシー ルし、JIS A 1153 に従って $\mathrm{CO}_{2}$ 濃度 $5.0 \%$ 、温度 $20^{\circ} \mathrm{C}$ 、湿度 $60 \% \mathrm{RH}$ の環境で促進中性化試験を開始した。中性化深さの測定は JIS A 1152 に準拠し、促進期間 4、8、13 および 26 週間に達した時に行 った。なお、材齢 56 日までに中性化が進行する可能性もあるため、 促進期間 0 日（促進中性化試験直前）にも中性化深さを測定した。

\subsection{3 シリーズIII（XRD 分析）}

促進中性化期間 26 週の供試体において、中性化の進行が最も大 きい表面部と最も小さい中心部の 2 箇所より試料を採取した。採取 した試料をハンマーで破砕し、 $5 \mathrm{~mm}$ のふるいを通過して $2.5 \mathrm{~mm} の$ ふるいに留まる大きさの破片を抽出した。これをアセトンに浸漬し て水和反応を停止させた。さらに、凍結真空乾燥機を用いて温度 $-50^{\circ} \mathrm{C}$ 、真空度 $7.0 \mathrm{pa}$ 以下の条件で乾燥させた。この試料を遊星型ボ ールミルで粉砕して $75 \mu \mathrm{m}$ のふるいを通過する大きさに微粉砕し、 XRD 分析に供した。

XRD 分析では、試料ホルダへの微粉末試料の詰め具合などが測定 結果に影響を及ぼすため、これを補正する目的で内部標準物質とし て $\mathrm{MgO}$ を内割りで $20 \mathrm{mass} \%$ 加え、遊星型ボールミルで微粉砕およ び混合して分析に用いた。分析条件は、ターゲット: $\mathrm{Cu}$ 、管電圧 : $40 \mathrm{kV}$ 、管電流 : $30 \mathrm{~mA}$ 、測定範囲 : $2 \theta=5 \sim 60^{\circ}$ 、ステップ角度 : $0.02^{\circ}$ 、計数時間 : 1 秒である。なお、主な測定対象は、 $\mathrm{Ca}(\mathrm{OH})_{2}$ および $\mathrm{CaCO}_{3}$ である。

また、XRD 分析に供した試料には骨材が含まれている。試料中の 骨材の含有割合によって $\mathrm{Ca}(\mathrm{OH})_{2}$ および $\mathrm{CaCO}_{3}$ の検出量が異なる。 そこで、骨材をコンクリート試料と同様な方法で微粉砕し、未水和 セメントと内割り (質量) で 10、20、30、40、50、60、70、80 お よび $90 \%$ の割合でそれぞれ混合した試料をXRD 分析することで検 量線を作成した。主な測定対象は骨材の主成分である $\mathrm{SiO}_{2}$ とした。 なお、 $\mathrm{FA}$ にも $\mathrm{SiO}_{2}$ が含まれるが、骨材と比較して微量であるため 無視した。この検量線を利用することで、促進中性化後のコンクリ ート試料に含まれる骨材の影響を補正した。
表 5 実験シリーズと湿潤養生期間

\begin{tabular}{|c|c|c|c|c|}
\hline \multirow{2}{*}{ 調合記号 } & \multirow{2}{*}{$\begin{array}{c}\text { 湿潤養生期間 } \\
\quad \text { (日) }\end{array}$} & \multicolumn{3}{|c|}{ 実験シリーズ } \\
\hline & & I & II & III \\
\hline 30PL & 7 & 0 & 0 & - \\
\hline 40PL & 7 & 0 & 0 & - \\
\hline 40FA33 & 7 & 0 & 0 & - \\
\hline \multirow{4}{*}{$50 \mathrm{PL}$} & 3 & \multirow{4}{*}{ O } & \multirow{3}{*}{ O } & - \\
\hline & 7 & & & 0 \\
\hline & 10 & & & - \\
\hline & 継続 & & - & - \\
\hline \multirow{4}{*}{$50 \mathrm{FA} 25$} & 3 & \multirow{4}{*}{0} & \multirow{3}{*}{$\bigcirc$} & - \\
\hline & 7 & & & 0 \\
\hline & 10 & & & $=$ \\
\hline & 継続 & & - & - \\
\hline \multirow{4}{*}{ 50FA67 } & 3 & \multirow{4}{*}{0} & \multirow{3}{*}{$\bigcirc$} & - \\
\hline & 7 & & & - \\
\hline & 10 & & & - \\
\hline & 継続 & & - & - \\
\hline $60 \mathrm{PL}$ & 7 & O & 0 & 0 \\
\hline $60 \mathrm{FA} 20$ & 7 & 0 & O & 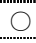 \\
\hline $60 \mathrm{FA} 50$ & 7 & 0 & 0 & - \\
\hline $70 \mathrm{PL}$ & 7 & 0 & - & - \\
\hline 70FA17 & 7 & 0 & $=$ & $=$ \\
\hline 70FA40 & 7 & $\bigcirc$ & - & - \\
\hline
\end{tabular}

\section{3. 実験結果および考察}

\section{1 シリーズ I（圧縮強度）}

\section{1 .1 水セメント比 $(\mathrm{W} / \mathrm{C})$ と圧縮強度}

図 1 および図 2 に、水セメント比別に分類した圧縮強度を示寸。 ここでは FA を外割り混合したコンクリートの面から考察する。材 齢 28 日では、水セメント比 40 および $50 \%$ FA 外割り混合コンク リートは PL コンクリートよりも大きな圧縮強度を示した。これは、 FA のポゾラン反応に起因するものと考えられ、既往の研究 4),10)にお いても FA 外割り混合率の増加とともに圧縮強度が増加する傾向が 明らかにされている。この傾向は気中養生（湿潤養生 7 日）におい ても認められるが、標準養生の方が顕著であった。水セメント比 60 および $70 \%$ FA 外割り混合コンクリートは PL コンクリートと大 差のない圧縮強度を示し、気中養生（湿潤養生 7 日）では PL コン クリートの圧縮強度を下回る場合もあった。この原因として、既往 の研究 11),12)では FA のポゾラン反応率は材齢 28 日で $3 \%$ 程度とされ 


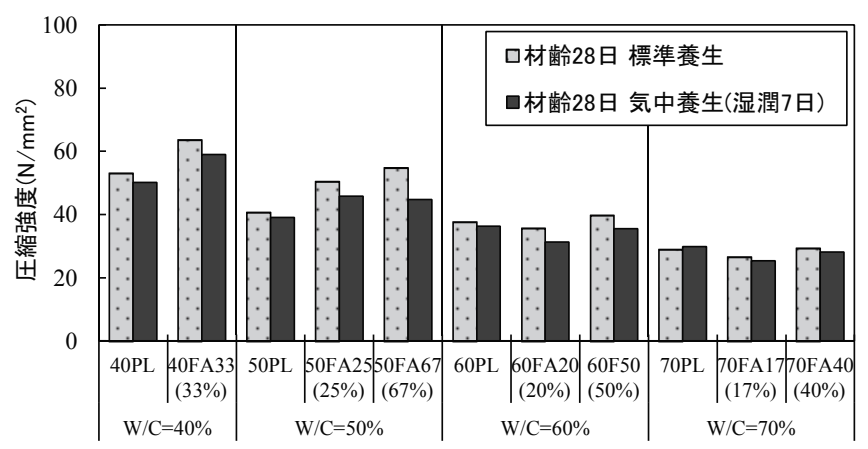

※( ) 内には、FA外割り混合率(\%)を示す。

図 1 水セメント比 $(\mathrm{W} / \mathrm{C})$ 別の圧縮強度（材齢 28 日）

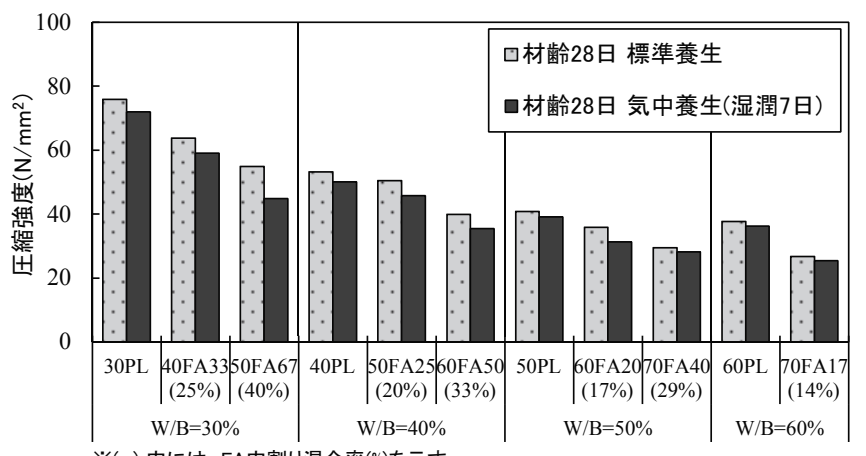

※( ) 内には、FA内割り混合率(\%)を示す。

図 3 水結合材比 (W/B) 別の圧縮強度（材齢 28 日）

ており、単位 $\mathrm{FA}$ 量の少ない水セメント比 60 および $70 \%$ ではポゾ ラン反応による圧縮強度への寄与効果が小さかったと考えられる。 60FA20 および 70FA14 では、特に単位 FA 量が少ないため、PL コ ンクリートと大差ない圧縮強度を示したものと推察される。

材齢 91 日では、水セメント比 40、50 および $60 \%$ のA 外割り混 合コンクリートが PL コンクリートよりも大きな圧縮強度を示した。 特に、標準養生した場合は FA 外割り混合コンクリートの材齢 28 から 91 日の強度増加が大きい。長期間にわたり水分が供給され、 FA のポゾラン反応が活発に進行したものと考えられる。また、 $50 \mathrm{FA} 25$ と 50FA67 の圧縮強度を比較すると、FA外割り混合率の増 加に伴う著しい圧縮強度の増加は認められなかった。この原因とし て、FA 外割り混合率の増加によりコンクリート $1 \mathrm{~m}^{3}$ を占める粉体 量（C+FA）が多量になる場合、圧縮強度の増進が停滞することが 知られている 13),14),15)。さらに、既往の研究 16),17)では FA のポゾラン 反応は $\mathrm{Ca}(\mathrm{OH})_{2}$ の濃度と量に影響を受けるとされ、50FA25 と $50 \mathrm{FA} 67$ は同じ水セメント比、寸なわち $\mathrm{Ca}(\mathrm{OH})_{2}$ の濃度と量は同等 と考えられるため、50FA67 では未反応の FA が多量に存在し、両 者に著しい強度差が生じなかったと推察される。一方、気中養生 (湿 潤養生 7 日) では材齢 28 から 91 日の強度増加が小さく、水分不足 により FA のポゾラン反応が十分に進行しなかったものと考えられ る。

\section{1 .2 水結合材比 $(\mathrm{W} / \mathrm{B})$ と圧縮強度}

図 3 および図 4 に、水結合材比別に分類した圧縮強度を示す。こ こでは FA を内割り混合したコンクリートの面から考察する。材齢 28 日では、寸べての FA 内割り混合コンクリートが PL コンクリー トよりも小さな圧縮強度を示した。材齢 28 日強度に対して、内割 り混合した FA はセメントほどの強度寄与効果を発揮しないことが

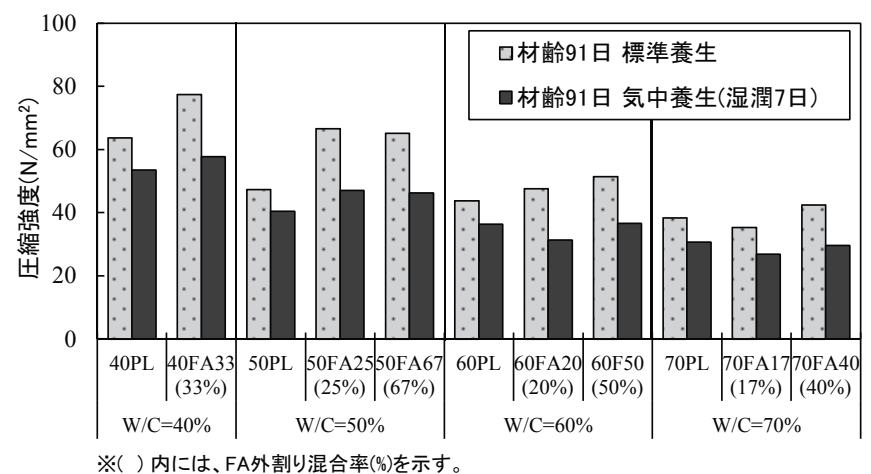

図 2 水セメント比 (W/C) 別の圧縮強度（材齢 91 日）

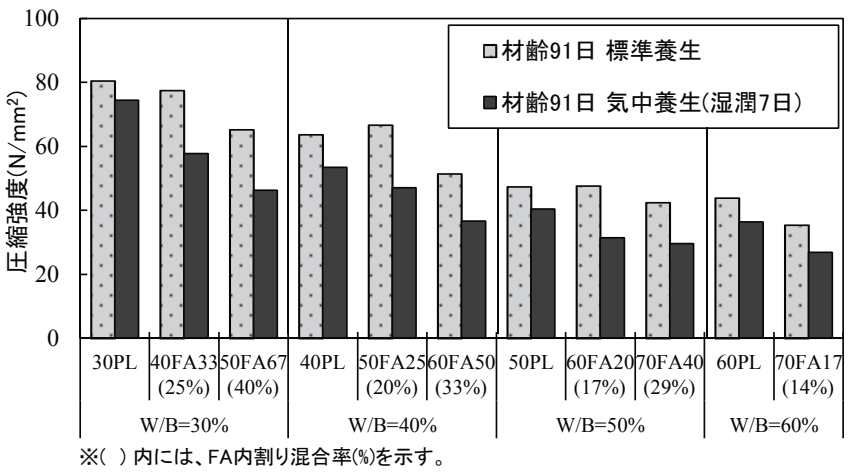

図 4 水結合材比 (W/B) 別の圧縮強度（材齢 91 日）

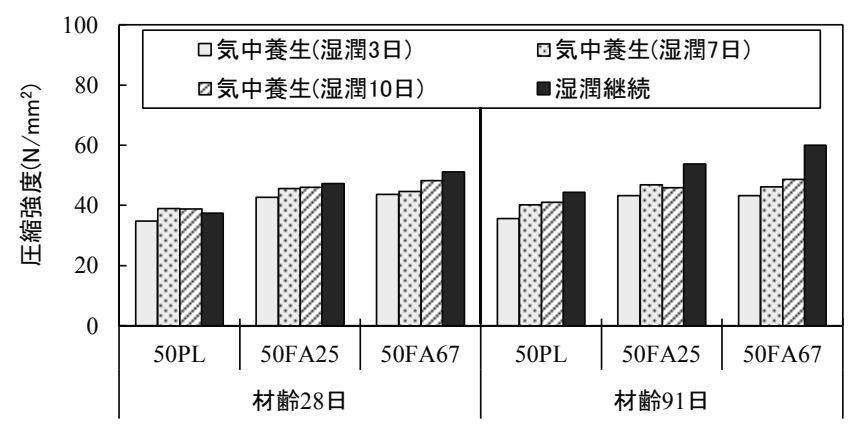

図 5 湿潤養生期間の違いによる圧縮強度の比較

わかる。

材齢 91 日では、吳らの研究 18),19)においても報告されているよう に、標準養生した 40FA33、50FA25 および 60FA20 は PL コンクリ 一トと同程度の圧縮強度を示した。長期間にわたり水分が供給され れば、FA 内割り混合率が $20 \%$ 程度で、W/B が $50 \%$ までであれば、 PL コンクリートと同程度の圧縮強度となることが示された。しか し、気中養生（湿潤養生 7 日）した場合は、材齢 28 および 91 日に 共通して、FA 内割り混合コンクリートは PL コンクリートよりも小 さな圧縮強度を示した。

\subsection{3 湿潤養生期間が異なる場合の圧縮強度}

図 5 に、水セメント比 $50 \%$ のコンクリートについて、湿潤養生期 間の違いによる圧縮強度の比較を示す。全体的に湿潤養生期間が長 いほど圧縮強度が大きい傾向が認められる。材齢 91 日では、気中 養生（湿潤養生 3 日）の圧縮強度が最も小さく、湿潤養生を継続し たコンクリートの圧縮強度が最も大きくなる傾向が明確であり、特 に 50FA25 および 50FA67 において顕著であった。FA のポゾラン 
反応は長期材齢において活発化するとされており 18),19)、ポゾラン反 応に必要な水分が長期間にわたって確保されるほど強度が増加寸る ことがわかる。

\section{2 シリーズ II（促進中性化）}

\subsection{1 水セメント比 $(\mathrm{W} / \mathrm{C})$ と中性化速度係数の関係}

コンクリートの中性化深さは材齢の平方根に比例することが知ら れており 20),21)、FA を混合したコンクリートについても同様の傾向

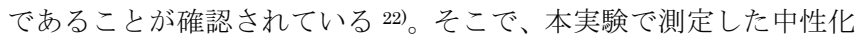
深さと促進期間の平方根の関係を最小二乗法により回帰分析し、促 進中性化速度係数（以降、中性化速度係数と表記）を求めた。なお、 促進期間 0 週において中性化深さを測定した結果、 $0 \mathrm{~mm}$ であった。

図 6 に、水セメント比別に分類した中性化速度係数を示す。ここ では FA を外割り混合したコンクリートの面から考察する。水セメ ント比 40\%では、40PL よりも40FA33 の方が若干小さな中性化速 度係数を示したが、大差はない。水セメント比 $50 \%$ では、 $50 \mathrm{PL} よ$ りも50FA25 の方が、標準養生および気中養生に共通して中性化速 度係数が小さい結果となった。3.1.1に示した圧縮強度から推測する と、水セメント比 40 および $50 \%$ では FA の外割り混合により圧縮 強度が増加したことから、ポゾラン反応による組織の緻密化が顕著 に進行したと考えられる。しかし、FA 外割り混合率の大きな 50FA67では、50FA25 よりも大きな中性化速度係数を示し、FAの ポゾラン反応による $\mathrm{Ca}(\mathrm{OH})_{2}$ の消費が著しかったと考えられる。水 セメント比 $60 \%$ では、60PL と比較して、60FA20 および $60 \mathrm{FA} 50$ の中性化速度係数は大きい結果となった。FA のポゾラン反応によ る組織の緻密化よりも $\mathrm{Ca}(\mathrm{OH})_{2}$ の消費の方が顕著に現れたものと 考えられる。したがって、水セメント比 $50 \%$ のA 外割り混合コン クリートではポゾラン反応による組織の緻密化に起因した中性化抑 制の傾向が著しく、反対に水セメント比 $60 \%$ のA 外割り混合コン クリートではポゾラン反応による $\mathrm{Ca}(\mathrm{OH})_{2}$ の消費に起因した中性 化促進の傾向が著しく認められた。すなわち、PL コンクリートで 見られる組織の緻密さ（圧縮強度）と中性化速度係数のような単純 な関係とは異なり、FA 外割り混合コンクリートでは FA のポゾラン 反応による組織の緻密化と $\mathrm{Ca}(\mathrm{OH})_{2}$ の消費が複雑に中性化進行に 影響を及ぼすことがわかる。

\subsection{2 水結合材比 $(\mathrm{W} / \mathrm{B})$ と中性化速度係数の関係}

図 7 に、水結合材比別に分類した中性化速度係数を示す。ここで はFAを内割り混合したコンクリートの面から考察する。全体的に、 同じ水結合材比では FA 内割り混合率が大きいほど中性化速度係数 が大きくなる。また、標準養生に比べて、気中養生（湿潤養生 7 日） の中性化速度係数が大きい。これらは、3.1.2 で示したように、FA 内割り混合コンクリートは同じ水結合材比の PL コンクリートより も圧縮強度が小さくなることから、コンクリート組織が粗であり、 コンクリート中への $\mathrm{CO}_{2}$ の侵入が容易になったことが原因と考え られる。さらに、同じ水結合材比の場合、FA 内割り混合コンクリ ートは PL コンクリートよりも単位セメント量が少ないため、セメ ントの水和反応で生成される $\mathrm{Ca}(\mathrm{OH})_{2}$ の量が少ないことも一因と して考えられる。なお、30PL では、養生方法に関わらず $0(\mathrm{~mm} /$ 、週）であった。

\subsection{3 湿潤養生期間と中性化速度係数の関係}

図 8 に、水セメント比 $50 \%$ について、湿潤養生期間の違いによる

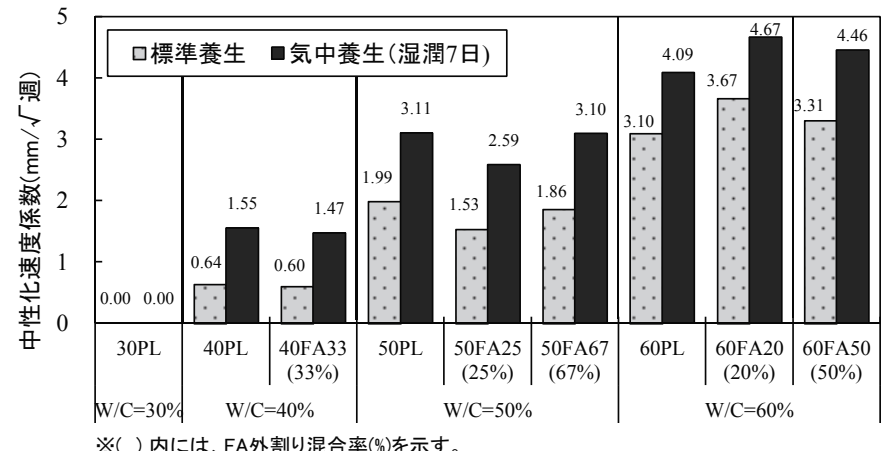

※( ) 内には、FA外割り混合率(\%)を示す。

図 6 水セメント比 (W/C) 別の中性化速度係数

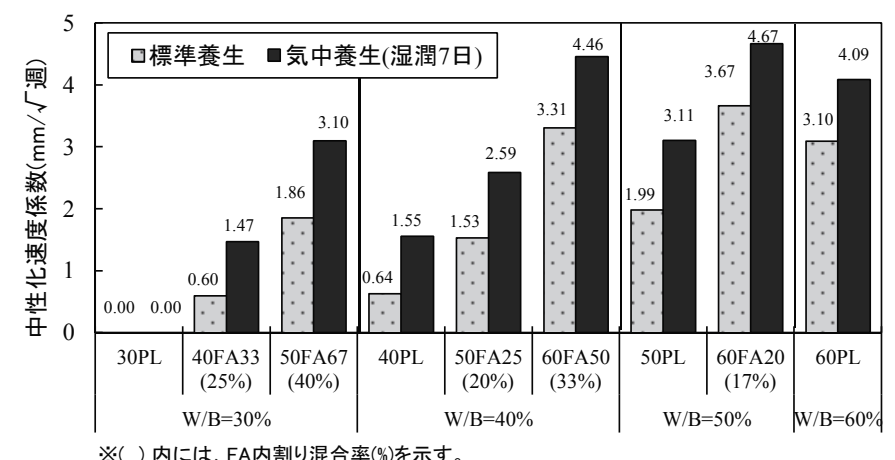

図 7 水結合材比 (W/B) 別の中性化速度係数

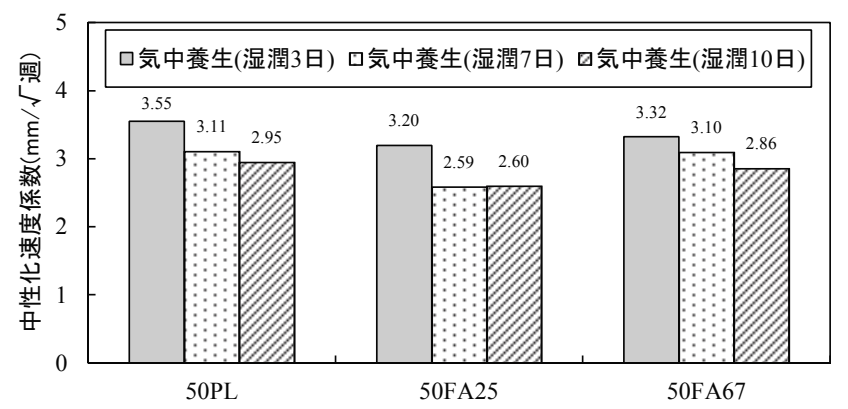

図 8 湿潤養生期間の違いによる中性化速度係数の比較

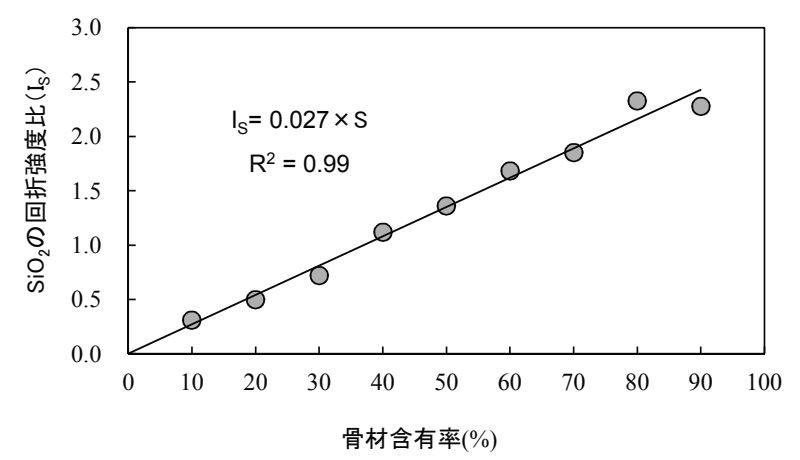

図 9 骨材含有率と $\mathrm{SiO}_{2}$ の回折強度比の関係

中性化速度係数の比較を示す。全体的に湿潤養生期間が長いほど中 性化速度係数が小さい傾向が認められる。すなわち、気中養生（湿 潤養生 3 日）の中性化速度係数が最も大きく、気中養生（湿潤養生 10 日）の中性化速度係数が最も小さい。

3.3 シリーズIII（X線回折分析）

$\mathrm{XRD}$ 分析により測定した回折強度 I（cps）を内部標準物質 $\mathrm{MgO}$ 
の回折強度 $\mathrm{I}_{\mathrm{MgO}}(\mathrm{cps})$ で除して回折強度比（I/ $\mathrm{I}_{\mathrm{MgO}}$ ）を求めた。さ らに、分析に使用した試料には骨材が含まれるため、2.3.3に示した 方法により図 9 に示すような検量線を作成し、次式を得た。

$$
\mathrm{I}_{\mathrm{S}}=0.027 \times \mathrm{S}
$$

ここで、 $\mathrm{I}_{\mathrm{S}}: 2 \theta=26.6^{\circ}$ における $\mathrm{SiO}_{2}$ の回折強度比 $\left(\mathrm{I} / \mathrm{I}_{\mathrm{MgO}}\right) 、 \mathrm{~S}$ : 骨材の含有率（\%）とする。（1）式より $\mathrm{S}$ が求められるので、次式 により補正を行うことができる。

$$
\mathrm{I}^{\prime}=\left(\mathrm{I} / \mathrm{I}_{\mathrm{MgO}}\right) /(100-\mathrm{S})
$$

ここで、I'：骨材含有率の補正を行った補正回折強度比とする。

図 10 に、 $\mathrm{Ca}(\mathrm{OH})_{2}$ および $\mathrm{CaCO}_{3}$ の特徵的なピークが見られる 2 $\theta=17^{\circ} \sim 35^{\circ}$ の分析結果を示す。 $\mathrm{Ca}(\mathrm{OH})_{2}$ のピークは $2 \theta=$ $18.0^{\circ}$ および $34.1^{\circ}$ に認められる。全体的に、表面部の方が中心部 よりも $\mathrm{Ca}(\mathrm{OH})_{2}$ の補正回折強度比が小さい。これは、 $\mathrm{CO}_{2}$ の侵入に よる中性化の影響と考えられる。また、FA 外割り混合コンクリー トでは、PL コンクリートよりも中心部の $\mathrm{Ca}(\mathrm{OH})_{2}$ 補正回折強度比 が小さい。これは、FAのポゾラン反応による $\mathrm{Ca}(\mathrm{OH})_{2}$ 消費の影響 と考えられる。

一方、 $\mathrm{CaCO}_{3}$ のピークは $2 \theta=29.4^{\circ}$ に認められる。全体的に、 $\mathrm{CO}_{2}$ の侵入により中性化の進行が速い表面部では、中心部よりも $\mathrm{CaCO}_{3}$ の補正回折強度比が大きい。50FA25 と 50PL の表面部にお ける $\mathrm{CaCO}_{3}$ 補正回折強度比を比較すると、50FA25 の方が小さい。 これは $\mathrm{FA}$ のポゾラン反応により $\mathrm{Ca}(\mathrm{OH})_{2}$ が消費されたことに加え、 組織が緻密化されて中性化の進行を抑制したことによると推測され る。また、60FA20 と 60PL の表面部における $\mathrm{CaCO}_{3}$ 補正回折強度 比を比較すると、60FA20 の方が小さいものの、その差は水セメン 卜比 $50 \%$ の場合のような大きなものではない。すなわち、水セメン 卜比 $60 \%$ では、FA外割り混合による組織の緻密化は顕著ではなく、 中性化進行を抑制する効果もあまり期待できないことが推測できる。 なお、中心部でも $\mathrm{CaCO}_{3}$ のピークが確認された。これは、既往の 文献 23)でも述べられているように、セメント製造工程における少量 混合成分として石灰石微粉末 $\left(\mathrm{CaCO}_{3}\right.$ を含む) が含まれていたこと による。

\section{FAの外割り混合が中性化に及ぼす影響の定量的検討}

\section{1 検討の方針}

ここでは、FA 外割り混合コンクリートを取り上げ、PL コンクリ ートに FA を外割り混合すると、中性化にどのような影響を及ぼす のかという観点から、その影響を定量的に検討する。コンクリート の中性化はセメントの水和反応で生成された $\mathrm{Ca}(\mathrm{OH})_{2}$ が大気中の $\mathrm{CO}_{2}$ と反応して $\mathrm{CaCO}_{3}$ に変化する現象であるが、FA外割り混合コ ンクリートでは FA のポゾラン反応により $\mathrm{Ca}(\mathrm{OH})_{2}$ が消費されるた め、PL コンクリートと比較して中性化の進行が早いと考えられる。 その一方、ポゾラン反応では、セメントの水和反応と同様な C-S-H ゲルや C-A-H ゲルが形成され 24,25)、コンクリート組織の緻密化に 寄与寸るため、大気中の $\mathrm{CO}_{2}$ の侵入に抵抗することが考えられる。 ここで、組織の緻密さを表す指標として、例えば細孔容積などがあ る。その一方で、山本らの研究 25),26)では細孔容積と圧縮強度には明 確な負の相関関係があることが示されている。このため、本研究で は組織の緻密さを表す指標として圧縮強度を用いることとした。以
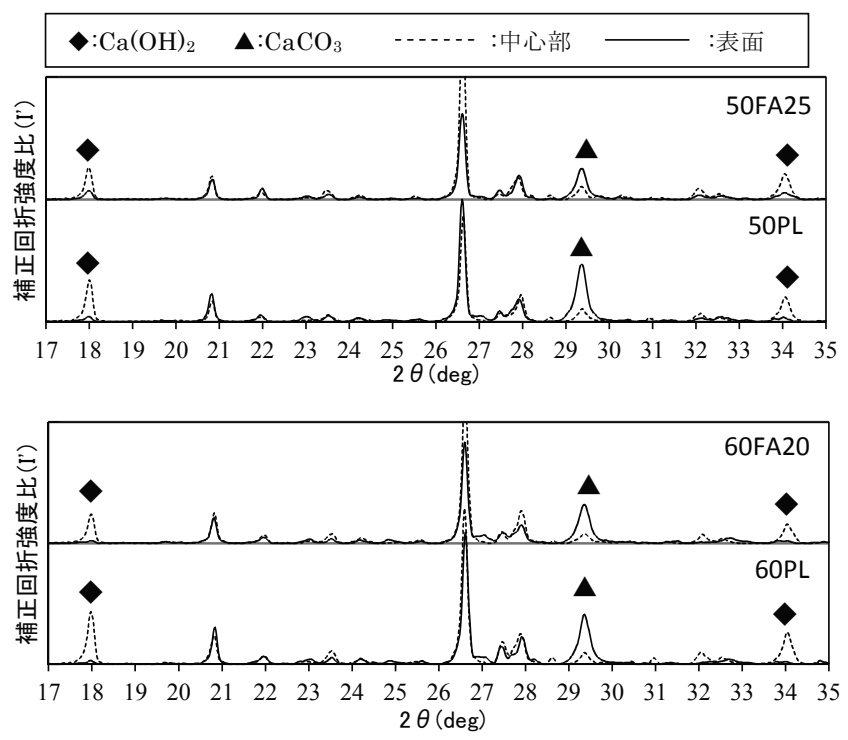

図 10 XRD 分析結果

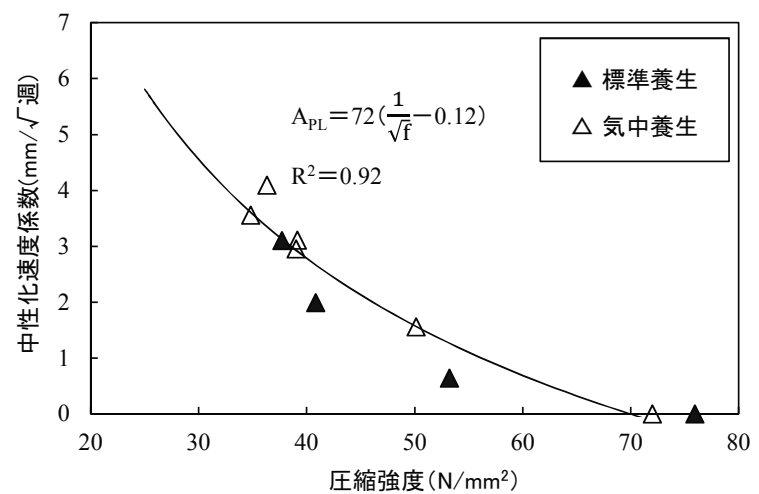

図 11 PL コンクリートの圧縮強度と中性化速度係数

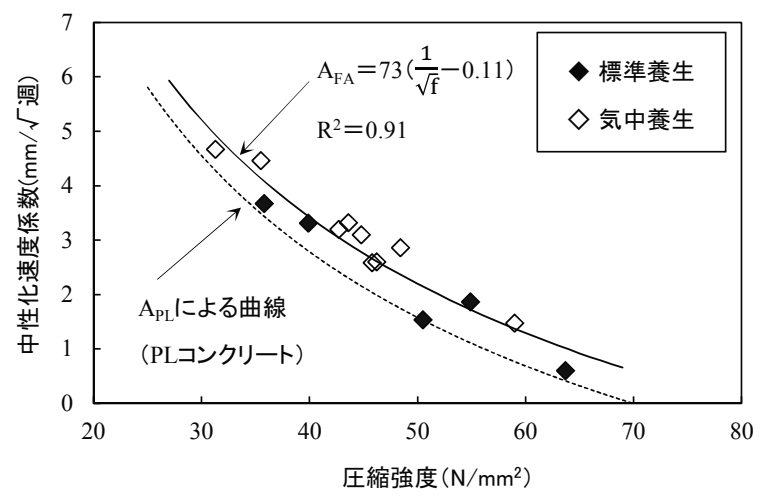

図 12 FA 外割り混合コンクリートの圧縮強度と中性化速度係数

降では、それら 2 つ影響について定量的に検討する。なお、中性 化速度係数を小さくし、中性化の進行を遅くする性質を中性化抵抗 性と定義する。

\section{$4.2 \mathrm{FA}$ 外割り混合による強度増加と中性化抵抗性}

\subsection{1 圧縮強度と中性化速度係数の関係}

圧縮強度と中性化には密接な関係があることが知られている。そ こで、圧縮強度と中性化速度係数の関係について検討した。図 11 に、標準養生および気中養生（湿潤養生 $3 、 7$ および 10 日）した $\mathrm{PL}$ コンクリートの材齢 28 日における圧縮強度と中性化速度係数の 
関係を示す。なお、2.3.2 に示したように、本研究では材齢 28 日ま でが所定の養生期間であり、28 から 56 日は供試体の乾燥期間であ ることから、材齢 28 日の圧縮強度を取り上げた。長谷川らによる 研究 27)では、中性化速度係数は圧縮強度の平方根に反比例し、約 $60 \mathrm{~N} / \mathrm{mm}^{2}$ の圧縮強度で中性化速度係数が $0(\mathrm{~mm} / \sqrt{ }$ 週 $)$ になること が明らかにされている。ここでは、同研究 27)を参考にして、材齢 28 日の圧縮強度 $\mathrm{f}\left(\mathrm{N} / \mathrm{mm}^{2}\right)$ と中性化速度係数 $\mathrm{A}(\mathrm{mm} / \sqrt{ }$ 週 $)$ の関係を次 式により表した。

$$
\mathrm{A}=\mathrm{a}_{\mathrm{f}}\left(\frac{1}{\sqrt{\mathrm{f}}}-\mathrm{b}_{\mathrm{f}}\right)
$$

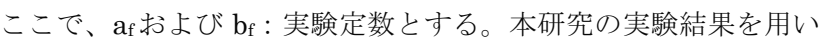
て、PL コンクリートの中性化速度係数 APL $(\mathrm{mm} / \sqrt{ }$ 週)に関する実験 定数 $\mathrm{a}_{\mathrm{f}}$ および $\mathrm{b}_{\mathrm{f}}$ を最小二乗法より求めたところ、 $\mathrm{a}_{\mathrm{f}}=72 、 \mathrm{~b}_{\mathrm{f}}=0.12$ となった。

さらに、図 12 に、FA 外割り混合コンクリートの材齢 28 日の圧 縮強度と中性化速度係数の関係を示す。(3) 式に従って FA 外割り 混合コンクリートの中性化速度係数 $\mathrm{A}_{\mathrm{FA}}(\mathrm{mm} / \sqrt{ }$ 週) に関する実験定 数 af および $\mathrm{bf}_{\mathrm{f}}$ の值を求めたところ、 $\mathrm{af}=73 、 \mathrm{~b}_{\mathrm{f}}=0.11$ となった。

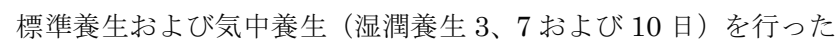
$\mathrm{FA}$ 外割り混合コンクリートでは、PL コンクリートと比較して、同 じ圧縮強度における中性化速度係数が大きい。これは、FAのポゾ ラン反応により圧縮強度が増加するが、その一方で $\mathrm{Ca}(\mathrm{OH})_{2}$ が消費 されるため、同じ圧縮強度で比較した場合、相対的に中性化抵抗性 が小さく評価されることを意味する。

\section{2 .2 強度増加が中性化に及ぼす影響}

FA 外割り混合コンクリートでは、PL コンクリートよりも大きな 強度増加が認められた。この強度増加は FA のポゾラン反応による 組織の緻密化に起因寸るものであり、中性化抵抗性に対してプラス の影響を与えると考えられる。図 13 は、この影響をモデル化した ものである。図中の P は、理論的にはポゾラン反応によってコンク リート中の $\mathrm{Ca}(\mathrm{OH})_{2}$ と $\mathrm{FA}$ （ポゾラン活性を有する部分）の両方が 残存することなく $100 \%$ 反応する時の FA/C の值であるが、コンク リート中の水分や材齢等の条件によっては両者が必ずしも $100 \%$ 反 応するとは限らない。 P までは FA 混合により圧縮強度が増加し、 中性化抵抗性も同様に増加するが、 $\mathrm{P}$ を超える領域では、強度およ び中性化抵抗性が一定になると考えられる。そこで、強度増加が中 性化に及ぼす影響を検討した。

図 14 は、圧縮強度と中性化速度係数の関係を表したものである。 ここでは、FA 外割り混合による強度増加の影響のみを考える。FA 外割り混合コンクリートが PL コンクリートに対して $\triangle \mathrm{f}$ だけ強度 増加した場合、中性化速度係数は次式に示寸ように $\Delta \mathrm{A} 1(\mathrm{~mm} / \sqrt{\text { 週 })}$ だけ変化する。

$$
\triangle \mathrm{A} 1=\mathrm{A}_{\mathrm{FA} 1}-\mathrm{A}_{\mathrm{PL} 1}=\mathrm{a}_{\mathrm{f}}\left(\frac{1}{\sqrt{\mathrm{f}_{\mathrm{FA}}}}-\frac{1}{\sqrt{\mathrm{f}_{\mathrm{PL}}}}\right)
$$

ここで、 $\mathrm{A}_{\mathrm{FA} 1}$ : FA 外割り混合コンクリートの圧縮強度から求めた 中性化速度係数 $(\mathrm{mm} / \sqrt{ }$ 週 $) 、 \mathrm{APL}_{\mathrm{PL}} \mathrm{PL}$ Pンクリートの圧縮強度か ら求めた中性化速度係数 $(\mathrm{mm} / \sqrt{\mathrm{r}}$ 週 $) 、 \mathrm{f}_{\mathrm{FA}}: \mathrm{FA}$ 外割り混合コンクリ ートの圧縮強度 $\left(\mathrm{N} / \mathrm{mm}^{2}\right) 、 \mathrm{f}_{\mathrm{PL}}$ : $\mathrm{PL}$ コンクリートの圧縮強度 $\left(\mathrm{N} / \mathrm{mm}^{2}\right)$ とする。なお、前記のとおり、本研究の実験結果を用いて PL コン クリートの af 值を求めたところ、72 であった。また、強度増加

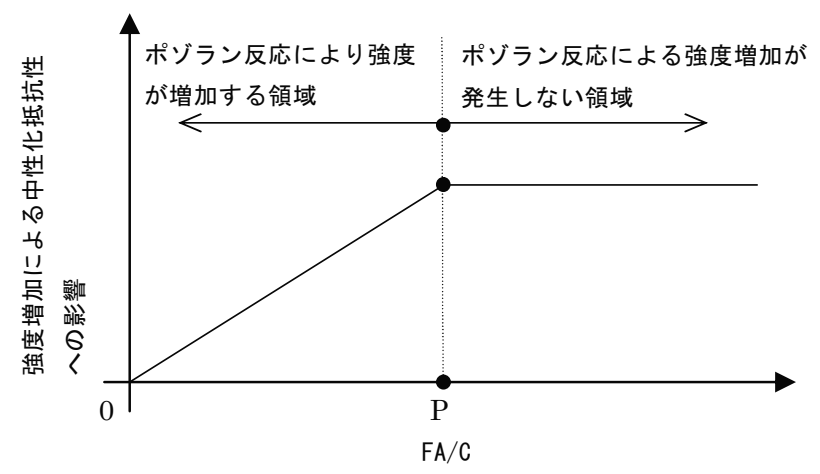

図 $13 \mathrm{FA} / \mathrm{C}$ と強度増加による中性化抵抗性への影響

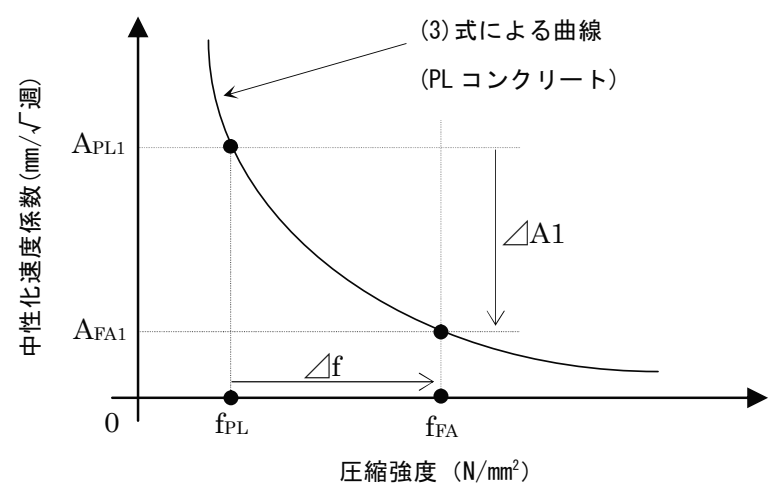

図 14 圧縮強度と中性化速度係数の関係

\begin{tabular}{|c|c|c|c|c|c|c|}
\hline \multirow{2}{*}{$\begin{array}{l}\text { 調合 } \\
\text { 記号 }\end{array}$} & \multicolumn{2}{|c|}{$\begin{array}{c}\mathrm{f}_{\mathrm{PL}} \text { または } \mathrm{f}_{\mathrm{FA}} \\
\left(\mathrm{N} / \mathrm{mm}^{2}\right)\end{array}$} & \multicolumn{2}{|c|}{$\begin{array}{l}\mathrm{APL1}_{\mathrm{PL}} \text { まは } \mathrm{A}_{\mathrm{FA} 1} \\
(\mathrm{~mm} / \sqrt{ } \text { 週 })\end{array}$} & \multicolumn{2}{|c|}{$\underset{(\mathrm{mm} / \sqrt{\sqrt{2} \text { 週 })}}{\triangle \mathrm{A} 1}$} \\
\hline & 標準 & 気中 & 標準 & 気中 & 標準 & 気中 \\
\hline 40PL & 53.2 & 50.1 & 1.27 & 1.57 & - & - \\
\hline 40FA33 & 63.7 & 59.0 & 0.41 & 0.77 & -0.85 & -0.80 \\
\hline $50 \mathrm{PL}$ & 40.8 & 39.1 & 2.67 & 2.92 & - & - \\
\hline $50 \mathrm{FA} 25$ & 50.5 & 45.8 & 1.53 & 2.04 & -1.14 & -0.88 \\
\hline 50FA67 & 54.9 & 44.8 & 1.11 & 2.16 & -1.56 & -0.76 \\
\hline $60 \mathrm{PL}$ & 37.7 & 36.3 & 3.13 & 3.35 & - & - \\
\hline 60FA20 & 35.8 & 31.3 & 3.44 & 4.28 & 0.31 & 0.92 \\
\hline $60 \mathrm{FA} 50$ & 39.9 & 35.5 & 2.80 & 3.49 & -0.33 & 0.13 \\
\hline
\end{tabular}

表 $6 \mathrm{FA}$ 外割り混合による強度増加の中性化速度係数への影響

※標準 : 標淮養生、気中 : 気中養生(湿潤 7 日)を示す。

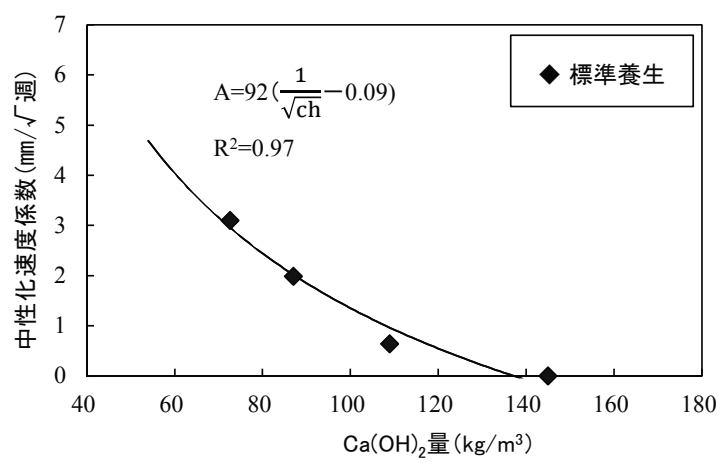

図 $15 \mathrm{Ca}(\mathrm{OH})_{2}$ 量と中性化速度係数の関係

により $\triangle \mathrm{A} 1$ は負の值となるが、中性化速度係数が減少することを 意味しており、中性化抵抗性にはプラスの影響となる。

表 6 に、3.1 で得られた圧縮強度のデータをもとに、（4）式より 計算した $\triangle \mathrm{A} 1$ の值を示寸。標準養生では、各調合に共通してポゾ 
ラン反応による強度増加が顕著であったため、中性化抵抗性にプラ スの影響が確認された。特に、水セメント比 $50 \%$ である $50 \mathrm{FA} 25$ お よび 50FA67 では、50PL と比較して FA 外割り混合によるプラス の影響が顕著であった。気中養生では、FA 外割り混合による強度 増加が標準養生ほど大きくなかったため、標準養生ほど中性化抵抗 性のプラスの影響は現れなかった。これは、脱型による水分の逸散 が、ポゾラン反応を停滞させたことが一因と考えられる。なお、 60FA20 では、60PL の圧縮強度を下回ったため、 $\triangle \mathrm{A} 1$ は正の值と なった。

\section{$4.3 \mathrm{FA}$ 外割り混合による $\mathrm{Ca}(\mathrm{OH})_{2}$ 消費と中性化抵抗性}

\subsection{1 コンクリート中の $\mathrm{Ca}(\mathrm{OH})_{2}$ 量と中性化速度係数}

$\mathrm{Ca}(\mathrm{OH})_{2}$ は、主にセメントの主成分である $\mathrm{C}_{3} \mathrm{~S}$ および $\mathrm{C}_{2} \mathrm{~S}$ の水和 反応により生成される。その反応は、次のような化学式で表せる 28)。

$\begin{array}{crrrr} & 2 \mathrm{C}_{3} \mathrm{~S}+6 \mathrm{H} \rightarrow \mathrm{C}_{3} \mathrm{~S}_{2} \mathrm{H}_{3}+3 \mathrm{CH} \cdots \cdots \cdots(5) \\ \text { 分子量 } & 456 & 108 & 342 & 222 \\ & 2 \mathrm{C}_{2} \mathrm{~S}+4 \mathrm{H} \rightarrow \mathrm{C}_{3} \mathrm{~S}_{2} \mathrm{H}_{3}+\mathrm{CH} \cdots \cdots \cdots \cdots(6) \\ \text { 分子量 } & 344 & 72 & 342 & 74\end{array}$

ここで、 $\mathrm{C}: \mathrm{CaO} 、 \mathrm{~S}: \mathrm{SiO}_{2} 、 \mathrm{H}: \mathrm{H}_{2} \mathrm{O} 、 \mathrm{CH}: \mathrm{Ca}(\mathrm{OH})_{2}$ とする。 これより、 $\mathrm{PL}$ コンクリート中の $\mathrm{Ca}(\mathrm{OH})_{2}$ の量 $\mathrm{ch}_{\mathrm{PL}}\left(\mathrm{kg} / \mathrm{m}^{3}\right)$ は次 式により表される。

$\operatorname{ch}_{\mathrm{PL}}=222 / 456 \cdot \mathrm{C} \cdot \mathrm{h}_{\mathrm{A}} \cdot \mathrm{R}_{\mathrm{A}} / 100+74 / 344 \cdot \mathrm{C} \cdot \mathrm{h}_{\mathrm{B}} \cdot \mathrm{R}_{\mathrm{B}} / 100$

ここで、 $\mathrm{C}$ : 単位セメント量 $\left(\mathrm{kg} / \mathrm{m}^{3}\right) 、 \mathrm{~h}_{\mathrm{A}}$ おび $\mathrm{h}_{\mathrm{B}}$ : セメント中 の $\mathrm{C}_{3} \mathrm{~S}$ および $\mathrm{C}_{2} \mathrm{~S}$ の質量割合、 $\mathrm{R}_{\mathrm{A}}$ および $\mathrm{R}_{\mathrm{B}}: \mathrm{C}_{3} \mathrm{~S}$ および $\mathrm{C}_{2} \mathrm{~S}$ の水 和反応率（\%）とする。水和反応率については、本研究で実測する ことができなかったため、既往の研究 29, 30, 31),32)を参考にして標準養 生の材齢 28 日における $\mathrm{R}_{\mathrm{A}}$ は $90 \%$ 、 $\mathrm{R}_{\mathrm{B}}$ は $40 \%$ と設定した。なお、 実際には水和反応率は調合条件により異なるが、す心゙ての調合で同 一と仮定した。また、コンクリート中の $\mathrm{Ca}(\mathrm{OH})_{2}$ 量と中性化速度係 数の関係は、既出の（3）式と同様に次式で表すこととした。

$$
\mathrm{A}=\mathrm{a}_{\mathrm{CH}}\left(\frac{1}{\sqrt{\mathrm{ch}}}-\mathrm{b}_{\mathrm{CH}}\right)
$$

ここで、ch : コンクリート中の $\mathrm{Ca}(\mathrm{OH})_{2}$ 量 $\left(\mathrm{kg} / \mathrm{m}^{3}\right) 、 \mathrm{acH}$ および $\mathrm{b}_{\mathrm{CH}}$ : 実験定数とする。

図 15 に、標準養生した $\mathrm{PL}$ コンクリート中の $\mathrm{Ca}(\mathrm{OH})_{2}$ 量と中性 化速度係数の関係を示す。（8）式に従って最小二乗法より実験定数 の值を求めたところ、 $\mathrm{a}_{\mathrm{CH}}=92 、 \mathrm{~b}_{\mathrm{CH}}=0.09$ であった。

\subsubsection{FA 外割り混合コンクリート中の $\mathrm{Ca}(\mathrm{OH})_{2}$ 量と 中性化速度係数}

FA 外割り混合コンクリートでは、ポゾラン反応による $\mathrm{Ca}(\mathrm{OH})_{2}$ の消費量を考慮する必要がある。 $\mathrm{FA}\left(\mathrm{SiO}_{2} 、 \mathrm{Al}_{2} \mathrm{O}_{3}\right.$ および $\mathrm{CaO}$ を 主成分とし、組成割合は既出の表 2 に示寸) のポゾラン反応は、次 の化学式で表せる 28 。

$\mathrm{FA}(10.3 \mathrm{~S}+2.5 \mathrm{~A}+0.3 \mathrm{C})+18.5 \mathrm{CH}+36.7 \mathrm{H} \rightarrow 10.3 \mathrm{C}_{1.1} \mathrm{SH}_{3.9}+2.5 \mathrm{C}_{3} \mathrm{AH}_{6}$

分子量の比 $1.00 \quad 1.37 \mathrm{G}_{\mathrm{FA}} \quad 0.66 \mathrm{G}_{\mathrm{FA}} \quad 1.98 \mathrm{G}_{\mathrm{FA}} \quad 0.95 \mathrm{G}_{\mathrm{FA}}$ ここで、 $\mathrm{A}: \mathrm{Al}_{2} \mathrm{O}_{3} 、 \mathrm{G}_{\mathrm{FA}}: \mathrm{FA}$ のガラス相の割合を示す。これによ り、 $1 \mathrm{~kg}$ の $\mathrm{FA}$ が消費する $\mathrm{Ca}(\mathrm{OH})_{2}$ の量は $1.37 \mathrm{G}_{\mathrm{FA}} \mathrm{kg}$ となり、FA 外割り混合コンクリート中の $\mathrm{Ca}(\mathrm{OH})_{2}$ 量 $\mathrm{ch}_{\mathrm{FA}}\left(\mathrm{kg} / \mathrm{m}^{3}\right)$ は、次式に より表すことができる。

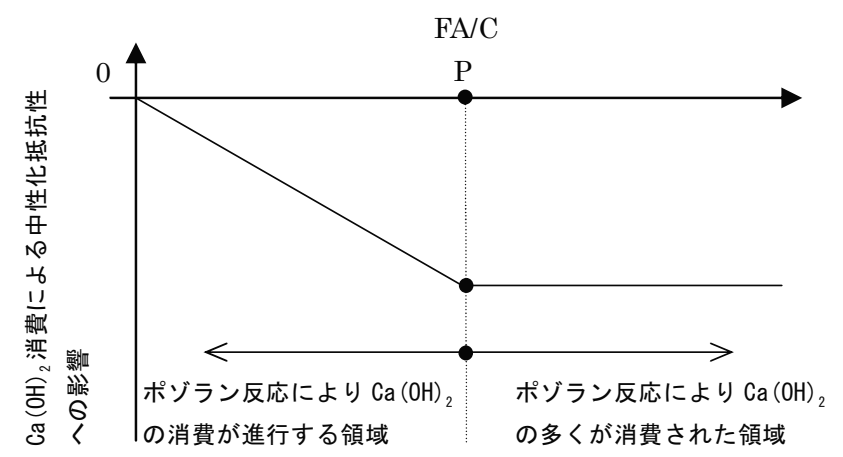

図 $16 \mathrm{FA} / \mathrm{C}$ と $\mathrm{Ca}(\mathrm{OH})_{2}$ 消費による中性化抵抗性への影響

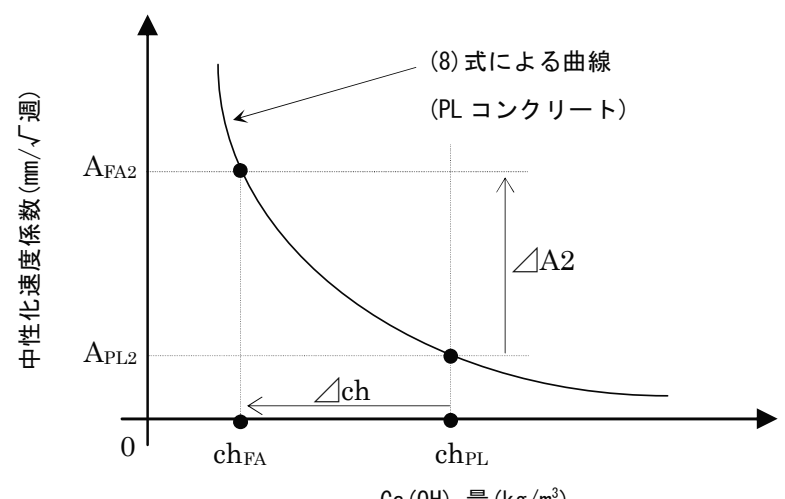

図 17 コンクリート中の $\mathrm{Ca}(\mathrm{OH})_{2}$ 量と中性化速度係数の関係

表 $7 \mathrm{FA}$ 外割り混合による $\mathrm{Ca}(\mathrm{OH})_{2}$ 消費の中性化速度係数 への影響

\begin{tabular}{|c|c|c|c|c|c|c|}
\hline \multirow{2}{*}{$\begin{array}{l}\text { 調合 } \\
\text { 記号 }\end{array}$} & \multicolumn{2}{|c|}{$\begin{array}{c}\mathrm{Ca}(\mathrm{OH})_{2} \text { 量 } \\
\left(\mathrm{kg} / \mathrm{m}^{3}\right)\end{array}$} & \multicolumn{2}{|c|}{$\begin{array}{c}\mathrm{APL} 2_{\text {または }} \text { A } \mathrm{FA2} \\
(\mathrm{mm} / \sqrt{ } \text { 週 })\end{array}$} & \multicolumn{2}{|c|}{$\begin{array}{c}\triangle \mathrm{A} 2 \\
(\mathrm{~mm} / \sqrt{\text { 週 })}\end{array}$} \\
\hline & 標準 & 気中 & 標準 & 気中 & 標準 & 気中 \\
\hline $40 \mathrm{PL}$ & 109 & 96 & 0.97 & 1.55 & - & - \\
\hline 40FA33 & 89 & 79 & 1.22 & 1.81 & 0.25 & 0.26 \\
\hline $50 \mathrm{PL}$ & 87 & 71 & 2.02 & 3.11 & - & - \\
\hline 50FA25 & 75 & 62 & 2.23 & 3.31 & 0.21 & 0.20 \\
\hline 50FA67 & 55 & 58 & 2.61 & 3.42 & 0.60 & 0.31 \\
\hline $60 \mathrm{PL}$ & 73 & 60 & 2.96 & 4.09 & - & - \\
\hline 60FA20 & 65 & 60 & 3.14 & 4.09 & 0.18 & 0.00 \\
\hline 60FA50 & 53 & 60 & 3.44 & 4.09 & 0.48 & 0.00 \\
\hline
\end{tabular}

$\operatorname{ch}_{\mathrm{FA}}=\operatorname{chPL}-1.37 \mathrm{G}_{\mathrm{FA}} \cdot \mathrm{FA} \cdot \mathrm{R}_{\mathrm{FA}} / 100$

ここで、FA: 単位 $\mathrm{FA}$ 量 $\left(\mathrm{kg} / \mathrm{m}^{3}\right) 、 \mathrm{R}_{\mathrm{FA}}$ : FA のポゾラン反応率 $(\%)$ とする。

FA のポゾラン反応率については、本研究で実測することができ なかったため、既往の研究報告を参考に設定する。宮原ら 12)によれ ば、ガラス相の割合が異なる FA を用いた場合においても、ポゾラ ン反応率に変化はないとし、材齢 28 日や 91 日では特にガラス相の 割合を考慮する必要はないとしている。また、既往の研究 11)によれ ば、材齢 28 日まで標準養生した場合のポゾラン反応率 $\mathrm{R}_{\mathrm{FA}(\mathrm{W})}(\%)$

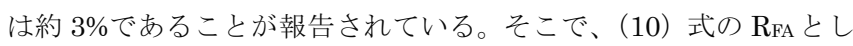
て、標準養生で $3 \%$ と、気中養生では次式のように FA 混合による 強度増加量をもとにポゾラン反応率を求めた。

$$
\mathrm{R}_{\mathrm{FA}(\mathrm{D})}=\frac{\Delta \mathrm{f}_{\mathrm{D}}}{\Delta \mathrm{f}_{\mathrm{W}}} \times \mathrm{R}_{\mathrm{FA}(\mathrm{W})}
$$


ここで、 $\mathrm{R}_{\mathrm{FA}(\mathrm{D})}$ ：気中養生におけるポゾラン反応率 $(\%) 、 \Delta \mathrm{f}_{\mathrm{D}}$ ： 気中養生における材齢 28 日の FA外割り混合コンクリートと PL コ ンクリートの強度差 $\left(\mathrm{N} / \mathrm{mm}^{2}\right) 、 \Delta \mathrm{f}_{\mathrm{W}}$ : 標準養生における材齢 28 日

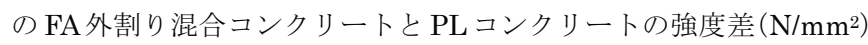

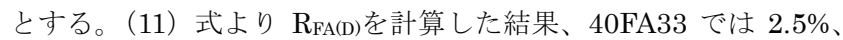
50FA25 では $2.1 \% 、 50 \mathrm{FA} 67$ では $1.2 \% 、 60 \mathrm{FA} 20$ および $60 \mathrm{FA} 50$ で はマイナスの值が算出されたため、 $0 \%$ とた。

表 7 に、（7）式および (10) 式を用いてコンクリート中の $\mathrm{Ca}(\mathrm{OH})_{2}$ 量を計算した結果を示す。なお、PL コンクリートの気中養生にお ける $\mathrm{C}_{3} \mathrm{~S}$ および $\mathrm{C}_{2} \mathrm{~S}$ の水和反応率については、参考となるデータが 入手できなかった。そこで、 3.2 に示した中性化速度係数の測定結 果を基にして、（8）式から逆算する方法で PL コンクリートの気中 養生における $\mathrm{Ca}(\mathrm{OH})_{2}$ 量を求めた。

\subsection{3 $\mathrm{Ca}(\mathrm{OH})_{2}$ の消費が中性化に及ぼす影響}

FA 外割り混合コンクリートでは、FA のポゾラン反応により $\mathrm{Ca}(\mathrm{OH})_{2}$ を消費するため、同じ圧縮強度の $\mathrm{PL}$ コンクリートと比較 して中性化の進行が早いと考えられる。ここでは、 $\mathrm{Ca}(\mathrm{OH})_{2}$ の消費 を中性化抵抗性へのマイナスの影響と捉えた。

図 16 は、同じ水セメント比のもと、 $\mathrm{FA} / \mathrm{C}$ と $\mathrm{FA}$ のポゾラン反応 による $\mathrm{Ca}(\mathrm{OH})_{2}$ の消費による中性化抵抗性に対するマイナスの影 響をモデル化したものである。 $\mathrm{FA} / \mathrm{C}$ の増加に伴い $\mathrm{P}$ までの領域で は、ポゾラン反応で $\mathrm{Ca}(\mathrm{OH})_{2}$ が消費されるため中性化抵抗性は減少 傾向となり、P 以降は一定となる。そこで、 $\mathrm{Ca}(\mathrm{OH})_{2}$ の消費が中性 化抵抗性に及ぼす影響をコンクリート中の $\mathrm{Ca}(\mathrm{OH})_{2}$ 量と中性化速 度係数の関係から検討する。

図 17 は、コンクリート中の $\mathrm{Ca}(\mathrm{OH})_{2}$ 量と中性化速度係数の関係 を表したものである。FA外割り混合コンクリートが PL コンクリー トに対して $\Delta \mathrm{ch}$ だけ $\mathrm{Ca}(\mathrm{OH})_{2}$ を多く消費した場合、中性化速度係

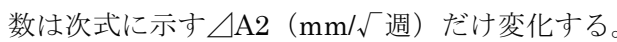

$$
\triangle \mathrm{A} 2=\mathrm{A}_{\mathrm{FA} 2}-\mathrm{A}_{\mathrm{PL} 2}=\mathrm{a}_{\mathrm{CH}}\left(\frac{1}{\sqrt{\mathrm{ch}_{\mathrm{FA}}}}-\frac{1}{\sqrt{\mathrm{ch}_{\mathrm{PL}}}}\right)
$$

ここで、 $\mathrm{A}_{\mathrm{FA} 2}: \mathrm{FA}$ 外割り混合コンクリートの $\mathrm{Ca}(\mathrm{OH})_{2}$ 量から求 めた中性化速度係数 $(\mathrm{mm} / \sqrt{ }$ 週 $) 、 \mathrm{ApL} 2: \mathrm{PL}$ コンクリートの $\mathrm{Ca}(\mathrm{OH})_{2}$ 量から求めた中性化速度係数 $(\mathrm{mm} / \sqrt{ }$ 週 $)$ と寸る。なお、 $\mathrm{Ca}(\mathrm{OH})_{2}$ の消費により $\triangle \mathrm{A} 2$ は正の值となるが、中性化速度係数が増加する ため、中性化抵抗性にはマイナスの影響となる。

既出の表 7 に、（8）式より計算した中性化速度係数と（12）式よ り計算した $\triangle \mathrm{A} 2$ を示す。標準養生では、ポゾラン反応が活発で $\mathrm{Ca}(\mathrm{OH})_{2}$ の消費が大きいため、同じ水セメント比では、FA の外割 り混合率が増加するほど $\mathrm{Ca}(\mathrm{OH})_{2}$ の消費が大きく、 $\triangle \mathrm{A} 2$ は大きく なった。気中養生では、ポゾラン反応率が標準養生と比較して小さ く、 $\mathrm{Ca}(\mathrm{OH})_{2}$ の消費も少ないため、FA 外割り混合率の違いによる $\triangle \mathrm{A} 2$ の差異は大きなものではなかった。

\section{4 ポゾラン反応による強度増加と $\mathrm{Ca}(\mathrm{OH})_{2}$ 消費を考慮した中性 化抵抗性の総合評価}

FA を外割り混合したコンクリートでは、ポゾラン反応により $\mathrm{Ca}(\mathrm{OH})_{2}$ を消費するため同じ圧縮強度の $\mathrm{PL}$ コンクリートよりも中 性化抵抗性が低下寸るが、組織の緻密化により PL コンクリートよ りも圧縮強度および中性化抵抗性を増加させる。そこで、強度増加 を指標とした組織の緻密化の影響と $\mathrm{Ca}(\mathrm{OH})_{2}$ 消費の影響を組み合
表 8 FA 外割り混合による中性化速度係数への影響

\begin{tabular}{|c|c|c|c|c|c|c|}
\hline \multirow[t]{2}{*}{ 調合記号 } & \multicolumn{2}{|c|}{$\begin{array}{l}\triangle \mathrm{A} 1+\triangle \mathrm{A} 2 \\
(\mathrm{~mm} / \sqrt{ } \text { 週 })\end{array}$} & \multicolumn{2}{|c|}{$\begin{array}{c}\mathrm{APL}_{\mathrm{PL}} \cdot \mathrm{A}_{\mathrm{FA}} \text { の計算值 } \\
(\mathrm{mm} / \sqrt{\text { 週 })}\end{array}$} & \multicolumn{2}{|c|}{$\begin{array}{c}\mathrm{A}_{\mathrm{PL}} \cdot \mathrm{A}_{\mathrm{FA}} \text { の実測值 } \\
(\mathrm{mm} / \sqrt{ } \text { 週 })\end{array}$} \\
\hline & 標準 & 気中 & 標準 & 気中 & 標準 & 気中 \\
\hline 40PL & - & - & 1.27 & 1.57 & 0.64 & 1.55 \\
\hline 40FA33 & -0.60 & -0.54 & 0.67 & 1.03 & 0.60 & 1.47 \\
\hline $50 \mathrm{PL}$ & - & - & 2.67 & 2.92 & 1.99 & 3.11 \\
\hline 50FA25 & -0.93 & -0.68 & 1.74 & 2.24 & 1.53 & 2.59 \\
\hline 50FA67 & -0.96 & -0.45 & 1.71 & 2.47 & 1.86 & 3.10 \\
\hline $60 \mathrm{PL}$ & - & - & 3.13 & 3.35 & 3.10 & 4.09 \\
\hline 60FA20 & 0.49 & 0.92 & 3.62 & 4.28 & 3.67 & 4.67 \\
\hline 60FA50 & 0.15 & 0.13 & 3.28 & 3.49 & 3.31 & 4.46 \\
\hline
\end{tabular}

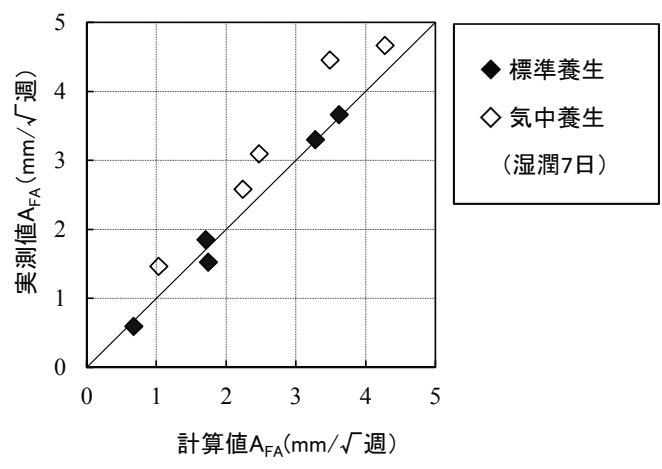

図 18 中性化速度係数の計算値と実測值の関係

わせることで、PL コンクリートに対する FA 外割り混合の影響を総 合的に（13）式で表す。なお、 $\mathrm{A}_{\mathrm{PL}}$ は、圧縮強度と中性化速度係数 の関係（(3) 式）より求めた。

$\mathrm{A}_{\mathrm{FA}}=\mathrm{A}_{\mathrm{PL}}+(\triangle \mathrm{A} 1+\triangle \mathrm{A} 2)$

表 8 に、中性化速度係数の計算結果を示す。標準養生では、50FA25 および 50FA67 で FA のポゾラン反応による組織の緻密化の影響が 大きく、中性化抵抗性が増加した。しかし、60FA20 および $60 \mathrm{FA} 50$ では、単位セメント量が他のコンクリートと比較して少ないうえ、 $\mathrm{FA} の \mathrm{Ca}(\mathrm{OH})_{2}$ 消費による影響が大きく、中性化抵抗性が減少した。 気中養生においても標準養生と同様の傾向を示した。全体的な FA 混合による中性化に対する影響について、水セメント比 $50 \%$ 以下の 場合は、中性化抵抗性に対寸るマイナスの影響は認められなかった。

図 18 に、本実験による中性化速度係数の計算值と実測值の関係 を示す。FA のポゾラン反応による強度増加に起因する中性化抵抗 性の増加と $\mathrm{Ca}(\mathrm{OH})_{2}$ の消費による減少の影響を組み合わせること により、FAの中性化に及ぼす影響を表すことができた。なお、本 研究では 1 種類の FA のみを使用したが、今後、他の種類の FA に ついても検討する必要がある。

\section{5. まとめ}

JIS A 6201 の II 種の品質に該当する FA を混合したコンクリート の中性化進行について検討し、本研究の範囲内で以下の結論を得た。 1) FA 外割り混合によるコンクリートの圧縮強度への影響を調查し た結果、標準養生、気中養生（湿潤養生 3、7、10 日間）および 湿潤養生に共通して、FA 外割り混合コンクリートは PL コンクリ 一トよりも大きな強度を示した。この傾向は、標準養生において、 特に顕著であった。

2) FA 外割り混合によるコンクリートの中性化一の影響を調查した 
結果、水セメント比 $40 \%$ では FA 外割り混合の有無による大きな 違いは認められなかった。水セメント比 $50 \%$ では、FA 外割り混 合率 $25 \%$ のコクリートは PL コンクリートよりも小さな中性化 速度係数を示した。水セメント比 $60 \%$ では、FA 外割り混合によ り PL コンクリートよりも大きな中性化速度係数を示した。

3) XRD 分析によってコンクリート中の $\mathrm{Ca}(\mathrm{OH})_{2}$ および $\mathrm{CaCO}_{3}$ を調 查した結果、FA 外割り混合コンクリートの中心部では、FAのポ ゾラン反応による $\mathrm{Ca}(\mathrm{OH})_{2}$ の消費が確認された。また、FA 外割 り混合コンクリートの表面部では、PL コンクリートの表面部と 比較して $\mathrm{CaCO}_{3}$ 量が少なく、ポゾラン反応による組織の緻密化 の影響が確認できた。

4) コンクリートの圧縮強度と中性化速度係数の関係から、FA のポ ゾラン反応による組織の緻密化（圧縮強度の増加）に起因した中 性化抵抗性へのプラスの影響を表すことができた。さらに、コン クリート中の $\mathrm{Ca}(\mathrm{OH})_{2}$ 量と中性化速度係数の関係から、FA のポ ゾラン反応による $\mathrm{Ca}(\mathrm{OH})_{2}$ 消費に起因した中性化抵抗性へのマ イナスの影響を表すことができた。

5) 同じ水セメント比のコンクリートにおいて、FA のポゾラン反応 による組織の緻密化（圧縮強度の増加）と $\mathrm{Ca}(\mathrm{OH})_{2}$ の消費の影響 を組み合わせて中性化抵抗性を検討したところ、コンクリートの 圧縮強度および $\mathrm{Ca}(\mathrm{OH})_{2}$ 量を指標とすることにより、 $\mathrm{FA}$ 外割り 混合コンクリートの中性化抵抗性を定量的に表すことができた。

\section{謝辞}

本研究を実施するにあたり、技術協力および材料提供をいただい た(株)関電パワーテック 和田正吾氏ならびに BASF ジャパン(株) 土谷正氏、馬場勇介氏に心より感謝申し上げます。なお、本研究は、 平成 26 年度「建築基準整備促進事業 M1 混合セメント等を使用し たコンクリートの耐久性に関する検討」（国住指第 1666-13 号）の 一部として実施したものである。

\section{参考文献}

1）呉富栄, 栘田佳寛 : フライアッシュコンクリートの中性化および而久設 計強度に関する一考察, 日本建築学会構造系論文集, 第 606 号, pp.15-19, 2006.8

2) 日本建築学会 : 建築工事標準仕様書・同解説 JASS 5 鉄筋コンクリー 卜工事, 2009

3） 日本建築学会：フライアッシュを使用するコンクリートの調合設計・施 工指針・同解説， 2007

4）黄光律，野口貴文，友澤史紀：フライアッシュを大量使用したコンクリ 一トの微細組織と圧縮強度, 日本建築学会構造系論文集, 第 517 号, pp.11-16, 1999.3

5）呉富栄, 桝田佳寛, 中村成春 : 高強度コンクリートにおけるフライアッ シュの強度寄与効果, 日本建築学会構造系論文集, 第 587 号, pp.1-6, 2005.1

6）黄光律 他 3 名：フライアッシュを外割混合使用したコンクリートの中 性化特性, コンクリート工学年次論文報告集, Vol.20, No.2, pp.127-132, 1998

7）黄光律，野口貴文，友澤史紀：フライアッシュを大量混和したコンクリ 一トの中性化特性に及ぼすポゾラン反応の影響, 日本建築学会構造系論 文集，第 531 号，pp.7-14，2000.5

8) 畑元浩樹, 平野利光 : 海外炭専燃発電所から発生する石炭灰を用いたコ ンクリートの性状について, コンクリート工学年次論文報告集, Vol.16, No.1, 1994

9) 本田悟, 椎葉大和 : 各種フライアッシュがコンクリートの諸特性に及ぼ す影響，コンクリート工学年次論文集，Vol.18，No.1，1996
10）高巣幸二，松藤泰典： $40^{\circ} \mathrm{C}$ 気中環境下におけるフライアッシュ外割混合 コンクリートの強度性状, コンクリート工学年次論文集, Vol.30, No.1, pp.201-206, 2008

11）大沢栄也，坂井悦郎，大門正機：フライアッシューセメント系水和にお けるフライアッシュの反応率, セメント・コンクリート論文集, No.53, pp.96-101, 1999

12）宮原茂禎 他 3 名: フライアッシューセメント系の水和反応, セメント・ コンクリート論文集, No.54, pp.50-55, 2000

13）船本憲治，古賀善雄，藤本浩：フライアッシュをセメント外割使用する コンクリートの基礎物性, セメント・コンクリート論文集, No.59, pp.524-530, 2005

14）古賀善雄, 船本憲治, 藤本浩 : フライアッシュを外割り使用したコンク リートの諸特性, コンクリート工学年次論文集, Vol.28, No.1, pp.1643-1648, 2006

15）芦田広喜，古賀善雄，藤本浩：フライアッシュを外割り使用したコンク リートの諸特性（2），コンクリート工学年次論文集，Vol.29，No.2， pp.511-516, 2007

16）佐伯竜彦，長㴰重義：フライアッシュと水酸化カルシウムの反応性に関 する基礎的研究，セメント・コンクリート論文集，No.51，pp.162-167, 1997

17）黄光律，野口貴文，友澤史紀 : フライアッシュを混合したコンクリート の圧縮強度発現推定式, 日本建築学会構造系論文集, 第 519 号, pp.1-6, 1999.5

18）只富栄，栘田佳寛，中村成春：フライアッシュを使用したコンクリート の長期強度発現に及ぼす湿潤養生の影響, コンクリート工学年次論文集, Vol.24, No.1, pp.315-320, 2002

19）乶富栄 他 3 名：フライアッシュを使用したコンクリートの強度発現に 及ぼす養生変化の影響，コンクリート工学年次論文集，Vol.25，No.1 pp.569-574, 2003

20）和泉意登志：コンクリートの中性化に関する研究-その 1 関数式のあてはめ と構成材料の影響-, 日本建築学会構造系論文報告集, 第 394 号, pp.17-26, 1988.12

21）阿部道彦 他 5 名：コンクリートの促進中性化試験法の評価に関する研 究, 日本建築学会構造系論文報告集, 第 409 号, pp.1-10, 1990.3

22）全洪珠，嵩英雄：コンクリートの強度および耐久性に及ぼすフライアッ シュの種類・置換率の影響に関する実験的研究, 日本建築学会構造系論 文集，第 602 号，pp.1-7，2006.4

23）李曉赫 他 3 名：コンクリートの初期材齢における温度および湿潤養生 条件が中性化進行性に及ぼす影響，日本建築学会構造系論文集，第 703 号, pp.1215-1225, 2014.9

24) K. Ogawa, H. Uchikawa, K. Takemoto : THE MECHANISM OF HYDRATION IN THE SYSTEM $\mathrm{C}_{3} \mathrm{~S}$-POZZOLAN, Cement and Concrete Research, Vol.10, pp.683-696, 1980

25）山本武志，金津努：フライアッシュのポゾラン反応に伴う組織緻密化と 強度発現メカニズムの実験的考察，土木学会論文集 E, Vol.63，No.1， pp.52-65, 2007.1

26）山本武志, 廣永道彦：フライアッシュのポゾラン反応性を評価するため の促進化学試験法 (API 法) の適用性の拡張, コンクリート工学年次論 文集, Vol.30, No.1, 2008

27）長谷川拓哉, 千歩修：文献調査に基づく屋外の中性化進行予測, コンク リート工学年次論文集, Vol.28, No.1, pp.665-670, 2006

28）呉富栄，栘田佳寬，杉山央：フライアッシュを使用したセメントペース 卜の水和反応率およびモルタルの強度発現, 日本建築学会構造系論文集, 第 632 号, pp.1699-1706, 2008.10

29）中田英喜, 高橋俊之 : 選択溶解法と粉末 X 線回折法との併用によるセメ ント水和率の測定, セメント・コンクリート論文集, No.53, pp.116-121, 1999

30）杉山央, 安田正雪 : 各種形状・断面厚を有する高強度コンクリート部材 の温度履歴特性および強度特性に関する実験的研究, 日本建築学会構造 系論文集，第 594 号，pp.1-8，2005.8

31）松下哲郎 他 3 名：リートベルト解析によるセメントの水和反応の定量 解析, 日本建築学会構造系論文集, 第 623 号, pp.1-8, 2008.1

32) 丸山一平 他 4 名：エーライトおよびビーライトの水和反応速度に関す る研究-ポルトランドセメントの水和機構に関寸る研究 その $1-$, 日本建築学会 構造系論文集，第 650 号，pp.681-688，2010.4 


\title{
QUANTITATIVE STUDY ON CARBONATION PROGRESS \\ OF CONCRETE USING FLY ASH
}

\author{
Takumi ZAITSU* ${ }^{*}$, Hisashi SUGIYAMA**, Toshimitsu KOBAYASHI *** \\ and Hiroshi JINNAI****

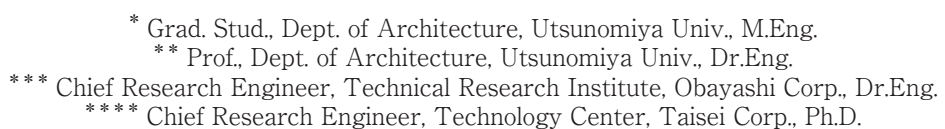

Fly ash (hereinafter abbreviated as FA) discharged from thermal power plants that use coal as the fuel is used as the mixture material for the purpose of improving performance after hardening and freshness of concrete or fly ash cement, which is obtained by replacing a part of Portland cement (hereinafter abbreviated as cement) with FA in concrete production. This is mainly because FA is a material with reactivity to $\mathrm{Ca}(\mathrm{OH})_{2}$ formed by hydration reaction of cement, and with the gel that is formed, concrete structure becomes dense and contributes to increase in strength. On the other hand, in pozzolanic reaction, for consuming $\mathrm{Ca}(\mathrm{OH})_{2}$, inhibition effect to carbonation may decrease compared to FA free concrete.

Therefore, we simultaneously studied increase in carbonation inhibition effect by densification of the concrete structure due to pozzolanic reaction and decrease in the same due to consumption of $\mathrm{Ca}(\mathrm{OH})_{2}$, and we attempted to shed light on the effect of mixing FA on the durability of concrete with the help of accelerated carbonation test. In specific terms, we regarded that increase in strength due to pozzolanic reaction had a positive effect on carbonation inhibition effect due to densification of structure, and furthermore, we regarded the consumption of $\mathrm{Ca}(\mathrm{OH})_{2}$ as a negative effect. By combining these effects, we comprehensively evaluated the durability of concrete by mixing FA. Besides, with regard to the sample where accelerated carbonation test was conducted, we used X-ray diffraction to investigate carbonation of $\mathrm{Ca}(\mathrm{OH})_{2}$ generated during hydration reaction of cement with $\mathrm{CO}_{2}$ and its consumption during pozzolanic reaction.

As a result, the following conclusions were drawn.

1) With regard to compressive strength of fly ash mixed concrete, in the case of same water-cement ratio, increase in compressive strength was significant in the $\mathrm{W} / \mathrm{C}=40 \%$ and $\mathrm{W} / \mathrm{C}=50 \%$ region.

2) With regard to carbonation of fly ash mixed concrete, as a result of using it in the accelerated carbonation test, in the case of same water-cement ratio, we could confirm equivalent or higher carbonation resistance at $\mathrm{W} / \mathrm{C}=40 \%$ and $\mathrm{W} / \mathrm{C}=50 \%$. However, at $\mathrm{WC}=60 \%$, carbonation inhibition effect was inferior compared to fly ash free concrete.

3) With regard to the results of $\mathrm{XRD}$ analysis, $\mathrm{CaCO}_{3}$ amount in the sample of the fly ash mixed concrete surface was less compared to the fly ash free concrete at center. Besides, with regard to $\mathrm{CaCO}_{3}$ amount in the sample of the central part of the fly ash mixed concrete, amount was smaller than the fly ash free concrete.

4) In the concrete having the same water-cement ratio, we studied carbonation inhibition effect by combining the effect of consumption of $\mathrm{Ca}(\mathrm{OH})_{2}$ due to pozzolanic reaction of fly ash and increase in compressive strength. Based on the compressive strength of concrete and $\mathrm{Ca}(\mathrm{OH})_{2}$ amount, we could demonstrate the carbonation inhibition effect of fly ash mixed concrete. 